Portland State University

PDXScholar

Summer 9-21-2017

\title{
The 2016 Presidential Election: Demographic Transformation and Racial Backlash
}

Skyler Lillian Brocker-Knapp

Portland State University

Follow this and additional works at: https://pdxscholar.library.pdx.edu/open_access_etds

Part of the American Studies Commons, and the Political Science Commons Let us know how access to this document benefits you.

Recommended Citation

Brocker-Knapp, Skyler Lillian, "The 2016 Presidential Election: Demographic Transformation and Racial Backlash" (2017). Dissertations and Theses. Paper 3827.

https://doi.org/10.15760/etd.5721

This Thesis is brought to you for free and open access. It has been accepted for inclusion in Dissertations and Theses by an authorized administrator of PDXScholar. Please contact us if we can make this document more accessible: pdxscholar@pdx.edu. 
The 2016 Presidential Election: Demographic Transformation and Racial Backlash

by

Skyler Lillian Brocker-Knapp

A thesis submitted in partial fulfillment of the

requirements for the degree of

\author{
Master of Arts \\ In \\ Political Science
}

\author{
Thesis Committee: \\ Kim M. Williams, Chair \\ Christopher Shortell \\ Ronald Tammen
}

Portland State University

2017 
(C) 2017 Skyler Lillian Brocker-Knapp 


\begin{abstract}
$\underline{\text { Abstract }}$
Despite analysts' predictions and assertions prior to the 2016 presidential election, the Hispanic vote did not prove decisive. Donald Trump's victory elucidates a new electoral calculus, one that will be ruled simultaneously by changing demographics and the backlash against such change. While Hispanic voters largely supported Hillary Clinton, structural and individual impediments hinder their access to the voting booth and their turnout on election day. This thesis explores the reasons why the Hispanic electorate did not prove decisive in the 2016 presidential election. It further illuminates the changing Electoral College map, in which the Midwest and the Rustbelt are determined by an older white electorate and the South and Southwest are determined by an influx of minorities and immigrants, namely the Hispanic electorate.
\end{abstract}

The 2016 presidential election illustrates the demographic changes and subsequent backlash that will persist over the next decade. A growing Hispanic population and electorate will eventually alter the political calculus of national and state elections, but turnout among white voters will continue to prove decisive in the near future. White backlash and transactional voting (e.g. economic, religious) clearly clinched Trump's success in crucial swing states, ultimately securing his Electoral College win. A review of polling prior to the 2016 election, as well as case studies of economic transactional and Hispanic Trump voters, demonstrates the breakdown across party and state lines that ensured Trump's Electoral College victory, despite a large and expanding Hispanic electorate. While it will continue to grow exponentially, it is unlikely that the Hispanic elec- 
torate will prove decisive as soon as the 2020 presidential election, but it will inevitably determine national and state elections within the next decade. 


\title{
$\underline{\text { Table of Contents }}$
}

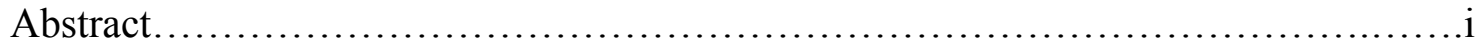

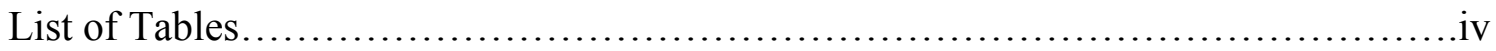

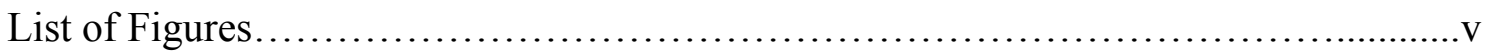

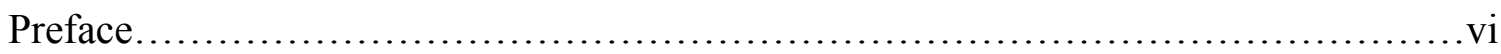

Chapter One: Scholarly Review of the Hispanic Electorate..........................

Chapter Two: The 2016 Presidential Election..................................45

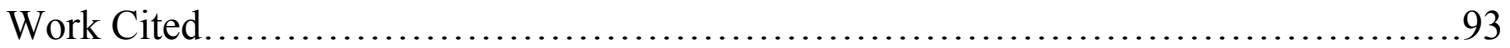




\section{$\underline{\text { List of Tables }}$}

Table 1 Hispanic Vote in Presidential Elections................................. 12 


\section{$\underline{\text { List of Figures }}$}

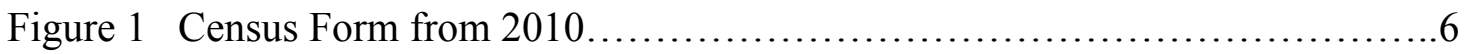

Figure 2 U.S.: Hispanic or Latino Origin Population Percentage, 2013 by State......72 


\section{$\underline{\text { Preface }}$}

The 2016 presidential election illuminates key elements in the U.S. electoratethe immediate electoral reality and the eventual demographic future. Both are integral explanatory factors in any analysis of the 2016 election and provide a clear present picture and long term view of the current and future Electoral College calculus. The Hispanic electorate is the demographic "sleeping giant" that analysts and social scientists have been heralding for years, but, due to structural and individual impediments, this effect will not be realized for years, possibly decades, to come. Demographic change is occurring everyday and significant and electorally impactful change is inevitable, but it clearly does not currently rise to the electoral importance that so many analysts have promulgated for years.

The 2016 presidential election is an anomaly in that economic (mostly white) voters ushered Donald Trump into the presidency (along with voters seeking specific religious, racial and gender policies), despite the inevitability of America's demographic future in which the Hispanic electorate will have a decisive role in national and local elections in the years to come. The duality of these two political trends is the subject of this analysis as the U.S. electorate grapples with outsized white support for Trump and the projected Latino turnout in future elections. In order to evaluate why the Hispanic electorate did not prove decisive in the 2016 U.S. presidential election, I review structural and individual factors that inhibit turnout among the Hispanic electorate. I argue that voting eligibility, civic education, English language proficiency, concentration of the Hispanic electorate, and backlash against immigrant and Hispanic voters all inhibit voting 
among the Hispanic electorate and consequently ensure a representation gap at the polls that was evident in the 2016 presidential election. The election illuminates voting impediments that currently hinder Hispanic voters, but also the inevitable long term trajectory of the decisive nature of the Hispanic electorate in state and national elections. The Hispanic electorate may not be poised to determine the 2020 presidential election, but within the decade, its sheer growth will nullify the effect of some structural and individual impediments.

The 2016 presidential election elucidated various critical factors that are not only decisive in the short term, but will grow to be integral in future elections. White voters, including a subset of economic or "transactional" voters (who voted for Trump solely in order to receive something in return, in this case economically, but others sought ideological validation, etc.), narrowly handed Trump a victory in crucial swing states. Latino voters, an electorate that stands to grow considerably in the coming decades, demonstrated their eventual, but certainly not immediate, decisive nature in swing states and throughout the country. Southern and western states continue to change demographically, with influxes of immigrants, particularly younger second-generation Hispanic immigrants who will eventually be eligible to vote. Midwestern and Rust Belt states simultaneously grow older and whiter, demonstrating a short term surge of Republican support, or at least Trump support. Trump's Electoral College victory illuminates the voting power of the white electorate, as well as economic or transactional voters who wished to benefit from Trump's promised policies, while simultaneously proving that the Hispanic electorate is not yet a decisive Democratic constituency in presidential elections. The 2016 
presidential election starkly showcased these short term and long term electoral trends, along with the changing Electoral College calculus that is best viewed through key swing states.

Arizona, Colorado, Florida and Texas best demonstrate the national demographic trajectory and provide a window into America's electoral future. Hispanic populations in these states have grown substantially over the past decade and show signs of a powerful Hispanic electorate. While all haven't reached a threshold at which the Hispanic electorate is decisive in national elections, that turning point is not far off. Trump's successful targeting and mobilization of white and transactional voters in specific areas (i.e., rural midwestern counties) proved sufficient in overcoming his deficit among minority voters. This Electoral College win will not be repeated in future elections due to the everchanging swing states that will lean Democratic as Hispanic voters grow in eligibility and turnout. Hispanic voters who supported Trump demonstrate that this electorate is hardly monolithic, but the Republican Party continues to alienate the majority of Hispanic voters with their immigration policy platform and contribution to the immigrant threat narrative. If the two major political parties maintain their current immigration policy platforms, Hispanics will likely continue to largely support Democrats as a powerful, growing electorate.

This paper is organized as follows. Chapter one contains the literature review which outlines various social science theories related to the Hispanic electorate and white voters, giving context to this thesis. I specifically cover the Hispanic electorate and transactional voters (in an economic context). These two electorates frame the entirety of my viii 
work and represent the central variables in the main argument. Next, I explore the white voter mobilization executed by the Trump campaign and subsequently, a review of polling and analysis done in the wake of the 2016 presidential election. Case studies of Hispanic Trump voters illuminate a group that straddles two often divergent electorates and identities. Finally, a review of four critical swing states_Florida, Colorado, Arizona, and Texas - demonstrates the degree to which future elections will be determined by the growing Hispanic electorate that is causing political scientists to reevaluate the traditional Electoral College map and realize a new calculus in U.S. presidential elections. Conclusions emphasize how future elections will be determined by demographic changes and a new Electoral College calculus. I argue that previous Republican strongholds will become swing states (e.g., Texas, Arizona) as the Hispanic electorate grows and relocates within the U.S. The Hispanic electorate did not prove decisive in the 2016 election, but demographics demonstrate an eventual minority majority in the U.S. voting population that will surely affect local and national elections in the decades to come. 


\section{Chapter One: Scholarly Review of the Hispanic Electorate}

\section{Literature Review}

The diversification of American communities is occurring, in part, because of immigration, interracial marriage, and ease of travel. Here, I focus on the impact immigration can have on the economic, social and electoral environment in states and counties throughout the U.S. Many political and social scientists argue that immigration, especially that of Hispanics, is necessary to maintain current production levels that demand a substantial labor force. Any rapid change in the demographic makeup of a country, however, undoubtedly forces changes and adjustments within its communities. White backlash, both socially and politically, is evident in political contests, especially those on the national stage.

The 2016 presidential election showcased the long term demographic changes that will affect all future elections, as Hispanic voters become more prominent and decisive in local and national politics. This process will likely take several election cycles, if current conditions remain the same, and is obviously not the decisive electorate that many (i.e. Judis and Teixeira's (2002) “emerging democratic majority" argument) argued it would be at the turn of the century. Donald Trump won despite his alienation of many Hispanic voters and immigrants, seemingly in contradiction to demographic analysis and academic prediction, by swaying sufficient white voters (including economic transactional voters) in critical swing states to win the Electoral College and thus the Presidency, despite losing the popular vote. Romney was unable to secure this coalition in 2012, in part, because of his lack of support among working-class voters. An analysis of the 2016 election out- 
lines the reasons for Trump's victory, while simultaneously demonstrating the future political calculus that is apparent in state and national demographic breakdowns.

Scholars largely agree that changing demographics, including an influx of Hispanic immigrants and eventual voters, will prove politically and economically consequential. Social scientists analyze these consequences and provide specific insights as to the effects of a growing Hispanic populace within the U.S. William Frey (2014) and Paul Taylor (2014) outline these changes and predict consequences, while Marisa Abrajano and Zoltan Hajnal (2015) demonstrate the backlash, evident among white voters in the U.S., to such demographic shifts. Daniel Hopkins (2010) argues that rapid change deeply affects political views of those within a destabilized community. The effects of demographic change also impact immigrant communities and can lead to "downward assimilation" among second generation immigrants according to Alejandro Portes and Rubén Rumbaut (2001). The positive economic consequences of immigration exist alongside the political turbulence and social backlash.

Significant research focused on the Hispanic population and electorate elicit further inquiry and evaluation, clearly presented in the 2016 presidential election. Tony Affigne (2000), as well as Renee Stepler and Mark Hugo Lopez (2016), offers analysis of these changes at the state level, particularly electoral transformations. Hispanics in the U.S., while growing in number, are underrepresented in the voting booth, as Loren Collingwood (2014) and John Judis and Ruy Teixeira (2002) outline in their respective research. In their analyses of political knowledge and democratic participation, William Crotty (1991) and Stephen Nicholson (2006) explain the gap between Hispanic and white 
voters at the voting booth, including political social capital and political knowledge. Nicholson (2006), along with Taylor (2014), Abrajano and Hajnal (2015), discusses various mechanisms to mobilize Hispanic voters. Barreto's (2008) research similarly illuminates the reasons Latinos vote and the techniques and social cues that encourage them to enter the voting booth. All of these structural factors continue to inhibit voter turnout among the Latino electorate, which in turn ensure a degree of impotency as a potentially decisive body.

Jackson (2011) outlines one theory of vote mobilization and vote choice, the partisan matching hypothesis, to highlight factors that contribute to priming the Hispanic voting bloc and influencing their voting decisions. Especially with respect to the Latino population in the U.S., social scientists agree that demographic expansion is economically and politically impactful. The 2016 presidential election, together with scholarly research of these demographic and electoral shifts, elucidates eventual and inevitable growth of a decisive Hispanic electorate, while simultaneously demonstrating the short term backlash that such rapid changes in U.S. communities can have on the political system. This thesis adds not only to the scholarly debate surrounding the diminishing white electorate by reviewing the 2016 election (including demographic breakdowns) and comparing it to past elections, but also by framing realistic expectations of Electoral College transformation with respect to the growing Hispanic electorate. Social scientists' decades-long foray into the decisive role the Hispanic electorate will play in presidential elections has yet to be realized and this thesis demonstrates the structural and individual impediments evident in the 2016 presidential election. 
NOTE: "Latino" is a term that encompasses a diverse group of people from various countries, backgrounds, and continents. It is a broad, and inaccurate term, but one that is frequently utilized to capture all immigrants, residents, and citizens within the U.S. with cultural, ethnic, and racial ties to Central and South America, as well as Spain. Some individuals who others would label "Latino" do not in fact identify as such, or vice versa. Self reporting on census forms is the manner in which the U.S. catalogues and identifies those of Hispanic descent living in the U.S. Our taxonomy system is inaccurate and should be taken with a dose of skepticism, but it is one of the few, if not only, comprehensive determinations of the ethnic and racial diversity in the U.S. The Latino population and electorate are not monolithic and the diversity inherent in each must be fully recognized. However, for want of a more accurate term, those currently used by scholars in the field, and those used in this analysis, to represent this group are "Latino" or "Hispanic".

Our taxonomy system is inaccurate and the Hispanic electorate is not monolithic Taylor (2014) argues that the current American designation of Hispanics is ineffective and inaccurate. Our census system fails to account for the diversity of the Hispanic population. He states that for centuries "we've used the 'one-drop rule' to settle such questions - if you're not all white, you're not white at all" (Taylor 7). Taylor (2014) alludes to the U.S. Census Bureau's policy of measuring race by counting anyone with any minuscule percentage of Hispanic, or African-American, or Asian ethnicity as non-white. He states that going forward "we'll need a more nuanced taxonomy" because "America 
isn't about to go color-blind; race is too hardwired into the human psyche" (ibid). On the other hand, as Taylor (2014) outlines in his analysis of the American generational divide, Millennials are far more diverse than previous generations and, consequently, are more at ease with the extensive demographic shifts underway in the U.S. (7). This fact may point to a larger acceptance of minorities in the future, but our current census system indicates an unwillingness to embrace the vast diversity of individuals in the U.S.

Taylor (2014) states that no group struggles more with our taxonomic system, containing many inaccurate and confusing race categories, than America's 53 million Hispanics (97). Hispanics are classified as an ethnic group, rather than a racial group by the federal government, one of the many reasons our system of taxonomy is ineffective and confusing (ibid). While Hispanics represent many bloodlines from various continents, they all have connections to the Spanish language, culture and heritage, which "are standard markers of ethnicity" (ibid). Taylor (2014) outlines the history of the Hispanic ethnic designation in the U.S.

The designation of Hispanics as an ethnic group was mandated by Congress in 1976 in response to pressure from Hispanic political and civil rights leaders who wanted official data about their community so they could press claims for equal treatment and benefits under the law. This was the first (and so far only) time in US history that an ethnic (as opposed to racial) group had been singled out this way. And it has led to a census form that, for many Hispanics, reads like a riddle. (97)

The confounding nature of the census form, with respect to Hispanics, leads to inaccurate, or at the very least confusing, results. Taylor (2014) states that questions eight and nine on the 10-question census form cover race and ethnicity (ibid). Question eight on the census form asked respondents if they are Hispanic, and to note their country of origin if 
they answer in the affirmative (ibid). Question nine asks respondents to state their race, giving them 15 options (ibid). Hispanic is not an option, but "some other race" and "mixed race and other" are options provided on the form (ibid). Figure 1 is the 2010 U.S. Census Bureau form that American residents filled out during the most recent census.

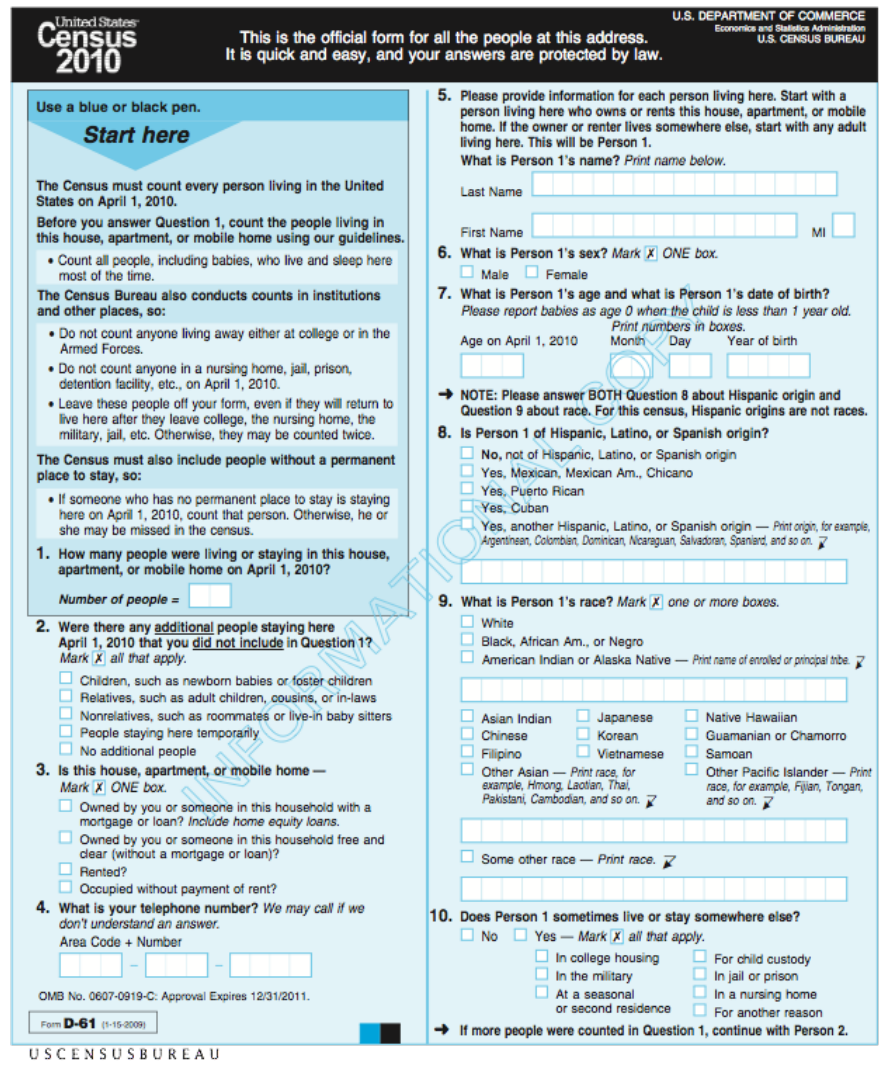

Figure 1-Census Form from 2010. Questions 8 and 9 involve ethnicity and race.

Taylor (2014) states for the 2010

census 53 percent of self-

identified Hispanics checked

"white", three percent checked

“black", and eight percent

checked "mixed race and other" (ibid). Taylor (2014) argues that

if 37 percent of Hispanics felt compelled to check "some other

race" on the 2010 census, because none of the other categories were representative, it is pertinent that the U.S. change its taxonomy (ibid). Adding Hispanic to the census form doesn't solve these complicated differences between race, ethnicity and country of origin. Many people who fall under the umbrella of what the U.S. consider "Hispanic" do not embrace that label, or that of "Latino" (ibid). These American terms fail to encompass the diversity within the Spanish-speaking and Spanish-cultural communities. Taylor (2014) states that according to a 2011 Pew Research Center survey, only 24 percent of Hispanic 
adults identify themselves by either "Hispanic" or "Latino" (ibid). Instead, 51 percent identify themselves by their family's country of origin, and 21 percent use "American" most often to identify themselves (ibid). Taylor (2014) argues that these two terms are likely simply an initial label that will recede over time, just as the labels for various European immigrants receded from the American vernacular (ibid). The only caveat of such a prediction is that European immigrants cut more ties with their extended families and their ancestral home, whereas many Hispanics remain deeply connected through the increased ease of communication and travel in the 21 st century (ibid).

Frey (2014) explains how new racial demographics are remaking America and specifically describes the nuanced nature of the Hispanic voting bloc. He argues that the "Hispanic vote is hardly monolithic, given the different national origins of its components" (Frey 219). Frey (2014) states that public perception often incorrectly conflates the Hispanic population with Mexican immigrants, but that the U.S. Latino population will increasingly be native-born Americans from a variety of origins (65). Breakdowns by national origin reveal that, at least historically, Cuban Americans tend to vote Republican, though that may change as subsequent generations are more removed from the constraints of socialism. Frey (2014) states that Protestant, particularly evangelical, Hispanics also lean Republican (219).

These evangelical Christian Hispanics are more swayed by moral values appeals, something George W. Bush capitalized on in the 2004 presidential election. Frey (2014) states that surveys suggest that in the 2012 election, "strong Democratic votes were cast by Dominicans, Puerto Ricans, and Mexicans in particular" (ibid). Analysis of such parti- 
san leanings can help candidates target likely supporters and communities, as well as allow social scientists to accurately evaluate policy priorities of influential constituencies. Frey (2014) asserts that "Hispanics are poised to make the greatest contribution to the nation's population growth in the foreseeable future" (65). The inevitable growth of the Hispanic voting bloc will demand recognition, positive policy prescriptions, and detailed analysis. It is also possible that as Hispanic immigrants, as a whole, assimilate more into American society, the electorate will grow increasingly Republican or mirror nonHispanic white voters in a variety of policy positions.

\section{Electoral Impact of the Hispanic Electorate}

Many political scientists highlight the affect a growing immigrant population can have on the U.S. electorate. This affect was clearly absent in the 2016 presidential election, and will likely not be realized in 2020, or even 2024. Despite the Hispanic electorate's lack of decisive impact, the growing Hispanic population is clearly a reality in the U.S. In his analysis of the generational divide evident in the U.S., Taylor (2014) uses the results of the 2012 presidential election to elucidate the vast demographic shifts currently at work. He demonstrates that the electorate in 2012 was the "most racially and ethnically diverse in our nation's history, a trend driven mainly by the tens of millions of Hispanic and Asian immigrants (and their children) who've come across our borders in the past half century" (Taylor 2). Further, the diversity of the electorate is an underestimation of the diversity of the U.S. population as a whole. While 26 percent of voters in the 2012 election were nonwhite, 37 percent of the total U.S. population were nonwhite in 2012 (ibid). Taylor (2014) notes that this deficit is due to many immigrants' young 
age, lack of citizenship, and political disengagement (ibid). The diversity within the general U.S. population ensures that the electorate will eventually diversify, as long as other factors do not inhibit voting among non-white electorates.

Hispanics and Asians comprise 22 percent of the U.S. population, but by 2060 that number will nearly double to 40 percent (Taylor 8). Half of all immigrants who arrived after the 1965 immigration wave hail from Latin America and just over a quarter from Asia (Taylor 71). Despite these projected demographic changes, social, cultural, and structural realities limit voter participation among immigrant groups, particularly among Hispanics. Taylor (2014), in line with Hispanic immigration scholars (e.g., Collingwood, Judis, Teixeira), argues that lack of formal education, citizenship status, and language barriers contribute greatly to lower socio-economic status and voter turnout in U.S. elections. Hispanic turnout in the the 2012 election fell slightly below 50 percent, at 48 percent (Taylor 85). Taylor (2014) states: “Three-quarters of all adult Hispanic immigrants have only a high school degree or less; half are in this country illegally; only a third speak English proficiently" (72). Their children, however, are often not resigned to the same fate as their parents, and will prosper through higher rates of post-secondary education, legal citizenship status, and English fluency. Taylor (2014) argues that the voter turnout deficit among Hispanics is a generational phenomenon. As the younger Hispanic demographic ages, voter turnout rates will rise, just as it did when previous generations of young Americans aged into adulthood (28).

Further contributing to Hispanics' anemic electoral participation is their lack of social trust. Taylor (2014) reports that 86 percent of Hispanics say you can't be too care- 
ful, with little difference between the first and second generations (75). Additionally, Taylor (2014) states that a "quarter of all immigrants (the vast majority Hispanic) arrived illegally and thus must navigate lives of stunted opportunity in the shadows of the law" (71). The debilitating social status of first generation illegal immigrants prevents upward mobility and cultural assimilation. Second generation immigrants also face consequences stemming from these structural and cultural adjustments. Alejandro Portes and Rubén Rumbaut (2001) argue that second generation immigrants encounter "segmented assimilation" depending on the human capital they have acquired and the context in which they use that capital (46). For example, educated immigrants are in "a much better competitive position," but contextual factors can hamper this advantage (ibid). Sociological contexts determine how immigrants can assimilate and succeed. Portes and Rumbaut (2001) state that children of immigrants face various external challenges in their social contexts that "may promote a set of undesirable outcomes" (e.g., dropping out of school, joining a gang) (59). Portes and Rumbaut (2001) label this path "downward assimilation," an example of when learned behavior in American society does not lead to "upward mobility but to exactly the opposite" (59). Downward mobility of second generation immigrants may contribute to lower turnout among young Hispanic voters, while first generation Hispanic immigrants may be more likely to share values with the GOP.

A lack of middle class jobs, that provided ladders to higher socio-economic statuses for previous generations of immigrants, have disappeared in the shadow of globalization and the digital revolution (Taylor 71). First generation Mexican immigrants, specifically, enjoy closer proximity and ease of communication to their country of origin, 
"reducing pressures to adopt America's language, customs, values, and mores" (ibid).

While many Hispanic immigrants continue to espouse the cultural values and practices of their countries of origin, most also adhere to principles common among recent immigrant groups. Taylor (2014) argues that while "today's immigrants—nearly 9 in 10 of whom are not Europeans" look differently than the immigrants from generations before, "when it comes to embracing what we think of as traditional American values, it's hard to find more fervent devotees" (4). These similar attitudes point toward a possible embrace of Hispanic immigrants and their families into the fabric of American society and culture. It remains unclear whether such an embrace would contribute to further electoral participation. The 2016 presidential election demonstrated the ineffectiveness of the Hispanic electorate in our current political reality, despite its continued growth.

Even when the Hispanic electorate grows sufficiently to prove decisive, and not just remain a minor contributing factor, large swaths of the electorate could vote Republican, creating a divide that essentially neutralizes the Hispanic vote. Many politicians and strategists have noted, from Ronald Reagan to Karl Rove (Senior Advisor to President George W. Bush), that immigrants share many values with the Republican Party (i.e., economic and religious conservatism). Yet, at the same time, the Republican Party does not garner the support of Hispanic voters. Rove wrote in 2013 that "if the GOP party doesn't find a way to do better with nonwhites, it not only risks extending its losing streak in presidential races, but eventually will put its congressional base at risk as well" (Taylor 85). The Republican Party stands to lose future electoral contests as immigration 
reform paves a pathway to citizenship, especially if the GOP continually fails to embrace any moderate policy proposal on immigration.

Taylor (2014) argues that such immigration reform worries the GOP, who could lose 11 million voters to the Democratic Party (85). As they become more deeply ingrained in society, Hispanic and Asian Americans and their adult children have steadily solidified their support for the Democratic Party (see Table 1) (Taylor 84). Lack of Hispanic support for Republican presidential candidates caused pundits to label the GOP the "pale, male, stale" party (Taylor 84, 2). Under the advice of Karl Rove, though, Bush enjoyed unprecedented support from Hispanics. However, during the past few presidential elections, the Democratic Party has eroded the GOP gains. While their turnout is lackluster, Hispanics who do vote lean Democratic. Hispanic voters have also grown increasingly Democratic over the past 30 years. George W. Bush, on the other hand, was able to secure significant support among Hispanic voters in 2004.

Table 1-Hispanic Vote in Presidential Elections

\begin{tabular}{|l|l|l|l|l|l|}
\hline $\begin{array}{l}\text { Presidential } \\
\text { Election Year }\end{array}$ & 1980 & 1984 & 2004 & 2012 & 2012 \\
\hline $\begin{array}{l}\text { Hispanic Vote } \\
(\%)\end{array}$ & $\begin{array}{l}\text { Jimmy Carter } \\
\text { (D) }-56 \%\end{array}$ & $\begin{array}{l}\text { Ronald Reagan } \\
\text { (R) - 37\% }\end{array}$ & $\begin{array}{l}\text { George W. } \\
\text { Bush (R) - 44\% }\end{array}$ & $\begin{array}{l}\text { Mitt Romney } \\
(\mathrm{R})-27 \%\end{array}$ & $\begin{array}{l}\text { Barack } \\
\text { Obama (D) - } \\
71 \%\end{array}$ \\
\hline
\end{tabular}

Figures from Taylor, 8 and MacGillis, 54.

George W. Bush's support from Hispanics in the 2004 presidential election demonstrates the possibility of Hispanic endorsement of Republican presidential candi- 
dates. Abrajano et al's (2008) study of the 2004 election, specifically the Hispanic vote, elucidates the conditions under which Latinos will support a Republican candidate in record numbers. The authors demonstrate that while "economic concerns, education, and health care loomed large for Hispanics, the combined concern that many Hispanic voters had for moral values and national security trumped traditional domestic issues" (Abrajano et al. 379). As mentioned above, Bush and his advisors were able to court the Hispanic vote through religious and family values appeals, offering Christian transactional voters religious incentives. The unique circumstances of the 2004 election must be understood in light of the September 11 attacks on the World Trade Center towers in New York City. Hispanics typically care the most about "bread and butter" domestic issues, but national security and foreign policy weighed on many Americans' minds after those horrific events (ibid). Bush was able to define the narrative of the campaign, focusing on moral values and national security, greatly influencing the decisions made by Hispanic voters (ibid). Abrajano et al (2008) state that "instead of health care and education determining the vote decision of Hispanics, the issues of moral values and terrorism dominated how Hispanic voters cast their ballots" (ibid). Bush's campaign demonstrated the importance of moral values and the effectiveness of this issue in courting the Hispanic vote relative to the white vote (Abrajano et al. 380). Further, the unique circumstances of this election helped solidify Bush's unprecedented support among Latinos. As the authors state, it is a "context future Republican nominees cannot count on inheriting" (ibid).

The rapid growth of the Hispanic population, and eventual parity of the Hispanic electorate, ensures that Hispanics will continue to consequentially impact U.S. presiden- 
tial elections for the foreseeable future. Taylor (2014) argues that the current multi-hued electorate represents a lagging indicator of demographic trends, as a diverse transformation is underway due to consistent immigration from non-European countries (2). Frey (2014) corroborates, stating that even if immigration keeps pace or slows in the coming decades, "the existing Hispanic population is large enough to produce substantial increases in its population through natural increase" (66). This second generation of Hispanic and Asian immigrants are "doing better than the immigrant generation on key measures of socioeconomic attainment and cultural adaptation", while at the same time continuing in the vein of their parents by placing more "importance than other Americans do on such ‘traditional American values' as family, hard work, education, and career success" (Taylor 72). This trajectory will only continue as immigrants and their families become embedded into the fabric of American society.

Scholars have predicted the exponential increase of minorities in the U.S. and the moment when minorities will surpass the white population as the majority, often referring to it as the 'majority-minority' phenomenon. Affigne (2000) states that by 2020 current minority groups will together become the majority population, with the largest being Latinos who will comprise more than a quarter of the total U.S. population, a share that is already surpassed in several U.S. states (e.g., New Mexico, California, Texas) (524). Now that there are more than 50 million Hispanics in the U.S., the nation has crossed a profound threshold (Affigne 523). Hispanics, though, disproportionately live in Democratic strongholds (e.g. California and New York) where their electoral effect is minimal. 
As Hispanic immigrants, and their children, relocate to other states and even more rural counties, their electoral impact will increase, eventually proving decisive.

California is a prime example of the affect a decisive Hispanic electorate can have on state politics and politicians. The 1994 passage of Proposition 187, "the controversial ballot measure that sought to stem illegal immigration and address its costs by cutting off state services, including healthcare and public education, to those in the country illegally," is closely associated with Pete Wilson (Barabak 2017). Wilson, a California Republican who served as San Diego Mayor, California Senator and Governor of California, is often cited in conjunction with the proposition that many argue he used to ensure reelection in 1994 (ibid). His position simultaneously "antagonized and energized a burgeoning Latino population, in California and around the country" (ibid). Backlash against Wilson and Proposition 187 exemplifies the political power of a decisive Hispanic population and electorate within a state.

\section{$\underline{\text { Geographic Dispersion and Variation across States }}$}

The affects demographic changes have on political outcomes will be largely impacted by the geographical dispersion of minority populations, due to the U.S. electoral system. Frey (2014) argues that separate migration flows to "melting pot" areas by new immigrant minorities in search of opportunity and diverse communities and to "New Sun Belt" areas by older white migrants — seems to "portend a regional demographic balkanization" (8). Minorities, though, are also moving to what Frey terms the "New Sun Belt", expanding battleground states now available to Democrats that were previously Republican strongholds in the South and Mountain West (e.g., Colorado, Georgia) (Frey 18). On 
the flip side, as was evident in the most recent presidential election, aging whites in the static Heartland states could "turn former Democratic bastions in the industrial Midwest and Northeast toward the Republicans" (Frey 18-19). The political polarization of the U.S. electorate is only exacerbated by recent immigration and demographic expansion.

Frey (2014), like Hopkins (2010), discusses the unavoidable reality that white backlash is most common is regions where the cultural generation gap is most evident and where the increase of young minorities is most rapid (10). While these minorities will eventually integrate into their communities, regions and states, it is an assimilation that will occur unevenly, but without pause or reversal (ibid). Negative attitudes by older, white Americans toward young, diverse immigrants have been documented extensively. Pew Research Center released a poll in 2011 that showed only 23 percent of Baby Boomers and seniors regard the growing immigrant population in the U.S. as a change for the better, while 42 percent saw it as a change for the worse (Frey 32). More than 50 percent went even further and stated that the influx of newcomers from other countries "represents a threat to traditional U.S. values and customs" (ibid). Arizona represents the generational and racial divides that are existent, to a lesser extent, throughout the country. Its large generational gap, due to young immigrants and older retirees, and its recent Hispanic growth of 175 percent (from 1990-2010) make it the prime example of demographic tensions within the U.S. (Frey 38).

This divide was no more politically apparent than with the passage of the 2010 Support Our Law Enforcement and Safe Neighborhoods Act or Arizona Senate Bill 1070. Frey (2014) states that it was one of the strictest anti-immigration laws ever enacted by a 
state (39). Specific provisions required that legal residents carry documentation verifying their citizenship at all times; if these legal residents failed to produce such documentation when requested, they would be subject to arrest, detention, or even deportation (ibid). Unsurprisingly, a statewide poll conducted at the time the bill was signed into law split distinctly along a racial divide: " 65 percent of whites but only 21 percent of Hispanics were in favor of the new law" (ibid). Further exemplifying the generational divide, the law "was favored by 62 percent of those 55 years of age and older (across all races) but only 45 percent of those under the age of 35" (ibid). Abrajano and Hajnal (2015) state that polls show "that well over 60 percent of Americans approve of Arizona's controversial SB 1070," and its provisions that enable "law enforcement officials to stop anyone who they suspect is in this country without legal status" (31). This highly contentious legislation illuminated the defined schisms that exist within our nation today and that will endure for the foreseeable future. We are in a pivotal period for our racial demographic makeup, one that foreshadows a diverse future (Frey 12).

The geographic dispersion of Latinos, especially, signifies changes in state demographic breakdown that have affected and will continue to affect presidential elections through electoral college matchups. As of 2014, Pew Research Center recorded Latino populations of at least one million in California, Texas, Florida, New York, Arizona, New Jersey, and Colorado (Stepler and Lopez). According to Pew, nearly one-in-five Hispanics nationwide (19\%) reside in Texas, making the state-wide Hispanic population top 10 million in 2014 (ibid). Florida accounts for nearly one-in-ten (9\%) of the nation's Hispanics, with a Latino population of 4.8 million (ibid). Arizona similarly represents a 
large segment of the U.S. Hispanic population, with nearly one third (31\%) of its statewide population being Hispanic (ibid). Colorado, an important battleground state in presidential elections, along with Florida (and increasingly, Arizona and Texas) has the smallest Latino bloc of the four, but still boasts a 21\% Hispanic population (ibid). With population growth and the increased statewide presence of Hispanics, election of Latino public officials has become more commonplace (Affigne 524). Affigne (2000) argues that increasing Hispanic populations and concentrated Latino communities have become "crucial variables in the calculation of electoral mathematics" (ibid). However, turnout among the Hispanic electorate remains dismal.

The New Sun Belt, a term Frey (2014) uses to describe the diversification of the mountain west and the southeast regions of the U.S., is at the front lines of electoral shifts. Rapidly growing western states are receiving an influx of Hispanics and other minorities, while at the same time prosperous southern states are attracting minorities from other parts of the U.S. (Frey 231). Frey (2014) states that in Arizona, Nevada, and Georgia, minorities "contributed more than four-fifths to the growth of those states' electorates," with Hispanics accounting for more than one-half of the growth in Georgia's electorate (ibid). Additionally, minorities contributed "more than two-thirds to the increase in the eligible voter population in Texas and Florida and about one-half to the increase in Virginia", while Colorado and North Carolina, "two other quickly growing New Sun Belt states, exhibited substantial white growth—although minorities still accounted for about one-third of the new eligible voters" (Frey 232). 
Frey (2014) demonstrates that minorities were instrumental in the outcomes in the 2008 and 2012 presidential elections in five South and West battleground states, rendering the white Republican advantage, in those states, obsolete (235). This geographic movement within the U.S. expands the electoral map for Democrats, but simultaneously removes the battleground state label from states in the industrial midwest that are becoming increasingly less diverse as minorities flock to the growing and thriving western and southern states. The fact that minority populations in previous Republican bastions such as Texas, Georgia, and Arizona dominate the under-18 population in these states is a clear sign of future competitiveness in presidential elections (Frey 236).

Obama also impressively won battleground states in the slowly growing Heartland, such as Ohio and Pennsylvania (Frey 236). Hilary Clinton in the 2016 presidential election demonstrated the trajectory of these states toward a more white, conservative, Republican demographic, as they lose minority and young voters. Voters in Ohio and Pennsylvania were primarily white (83 and 85 percent, respectively) in 2012, but Obama was able to narrowly win both due to strong Democratic and minority turnout and simultaneous small white Republican voting margins compared to other states (ibid). Frey (2014) seems to accurately predict Clinton's narrow loss of these states when he argues that Ohio and Pennsylvania "were among the closest states in the 2012 election and point up a potential geographic fissure that may play out more vividly in future elections" (ibid). Obama's impressive electoral college victory, but narrow win in the Heartland, portended much of the 2016 election and the demographic and geographic changes at work around the country. Texas, a long-time Republican stronghold, is projected to have 
a minority-majority electorate in the next presidential election (ibid). This new reality will forever alter the political calculus of presidential elections, as the Electoral College math and map ensure retooling of past understandings if party propensities remain static (ibid). Any modern electoral reasoning now requires an understanding of demographic and geographic shifts that will impact all future electoral contests.

Demographic change will inevitably change the electoral map, but will be somewhat diminished by lower turnout among Hispanic voters. Jackson's (2011) study of Latino political identity and vote choice outlines lackluster Hispanic turnout through an illustration of the largest state in the country. California's total population surpasses 35 million, and its Latino population (the largest of any U.S. state) was nearly 15 million in 2014 (according to the Pew Research Center) (Jackson 696). Even in 2006, when Latinos made up approximately $32 \%$ of the state's population, they only comprised $14 \%$ of its voters (ibid). Jackson (2011) states that the Latino population in California is mostly of Mexican origin (84\%) and largely favors the Democratic Party (ibid). Jackson states that among Latino voters in California, "Democratic partisanship outnumbers Republican partisanship more than three to one, with $64 \%$ registered Democrats, $18 \%$ registered Republicans, and 14\% independents or minor party supporters" (ibid). While lack of Hispanic participation in local California elections may have a dramatic effect, California is a solidly Democratic state on the Electoral College map. Hispanic voters' low turnout in California for presidential elections does not alter the national election results, but it does demonstrate a phenomena that could prove impactful when replicated across the U.S. As 
Latino voters move to traditional Republican strongholds and increase their turnout they will eventually prove decisive in state and national elections.

\section{$\underline{\text { Turnout among Hispanic Voters }}$}

In order for this eventual impactful influence to manifest across the U.S., Hispanic voters will have to turn out at greater rates than they have thus far. Jackson (2011) reports that despite accounting for nearly $50 \%$ of the total U.S. population growth over the last few years, the Hispanic population continues to "lag behind whites and blacks in voter eligibility, registration, and turnout" (691). These numbers have remained historically low due to lack of citizenship, as well as younger age and socio-economic and education levels (692). These structural factors clearly contribute to the Hispanic electorate's ineffectiveness at determining presidential elections.

The discrepancy between the growing Hispanic population and the sluggish turnout rate among the Hispanic electorate can be seen as a "voter representation gap" in U.S. elections between whites and minorities (Frey 2014). Lack of citizenship among Hispanics, especially, hinders their turnout as a group. Further impediments exist due to individual or familial experiences. In her New York Times Magazine article "Dream in Blue," Marcela Valdes (2016) argues that a lack of civics education in U.S. schools, many of which only offer one class, if that, severely undermines students' future comprehension of voting and public policy issues (ibid). While this drought in civics education hurts all American students, Valdes (2016) concludes that it is devastating for Latinos (ibid). If children cannot hope to receive a civics education in school, some are able to learn by the example set by their parents, or in exposure to voting itself. Valdes (2016) states: "Sever- 
al studies have found that merely hearing parents chat about politics or watching them cast a ballot improves the odds that a child will later vote as an adult" ("Dream in Blue" 62). A national survey, directed by Mark Hugo Lopez in 2002, "found that young Latinos were the least likely to have discussed politics with their parents" and were the "most likely to believe that voting is 'difficult"' (ibid). The next generation of Latino voters face additional barriers at the voting booth, simply because many find it an enigmatic exercise.

A census survey taken during the 2012 election demonstrated the immense potential of this untapped minority group, as only 44 percent of Hispanics in the U.S. were eligible to vote (Frey 215). The same survey found that only 52 percent of Asians were eligible, while 69 and 79 percent of blacks and whites, respectively, were eligible in 2012 (ibid). This representation gap is further widened, as many Hispanics and Asians who are eligible to vote do not turn out (Frey 216). The Hispanic electorate is a potentially decisive voting bloc, but only if they increase turnout over the next several election cycles. The future decisive Hispanic electorate was somewhat evident in the 2012 election, as Obama's campaign mobilized an unprecedented amount of minority voters.

The 2012 election presented a window to future elections, in which minority voters will be better represented at the polls. Collingwood et al (2014) find, in their analysis of cross-racial mobilization, that while voter turnout "declined nationally from 2008 to 2012 by 2 percent, among Latinos there was a 28 percent increase in votes cast in 2012 (from 9.7 to 12.5 million)" (632). Traditionally low Latino turnout in political elections is easily explained through obvious factors such as citizenship, but it is also due to the fact 
that Latinos are younger, have fewer resources and are less connected to mainstream political networks and the political elites who enforce them (Collingwood et al. 632). It is clear that those factors that previously hampered Latino turnout, generated support for Barack Obama in 2012. Younger voters are more likely to vote Democratic, as are those at the lower end of the socio-economic spectrum, both factors largely evident among Latino voters. Obama's support of the DREAM (Development, Relief, and Education for Alien Minors) Act and his administration's DACA (Deferred Action for Childhood Arrivals) program demonstrated support for children of immigrants brought to the U.S. illegally. These policy positions almost surely encouraged Latino support for Obama.

The 2012 presidential election pointed to a future of presidential elections fueled by minority voters. Whites, in 2012, generated one of the largest margins in 30 years for Republicans, but Obama prevailed due to minority support (Frey 223). Frey (2014) argues that Obama's 2012 win demonstrates the "strength of the minority vote in American politics" and that it is "a strength that will need to be reckoned with by both parties in future elections" (ibid). Frey (2014) hypothesizes that if Romney could have eked out a victory with even higher white voter turnout, it "would have been the 'last hurrah' for a party strategy that relied primarily on whites as its base" (224). Clearly, the most recent presidential election of 2016 demonstrated that while demographic shifts point toward Democratic wins, geographic balkanization can skew the Electoral College in favor of white Republicans. Frey (2014) argues that Obama's 2012 coalition of "supersized minority outreach and turnout efforts" while simultaneously losing an historically large amount of white voters, "is not a viable longterm strategy either" (ibid). Minorities are 
the demographic future, but white Americans still control large swaths of the electoral landscape.

America's future includes a demographic restructuring that will undoubtedly impact current and future elections, whether white Americans embrace or actively oppose their real and perceived loss of electoral leverage. Frey (2014) astutely recognizes the affect new racial demographics will have on remaking America in a more diverse image.

The projected rise in the minority portion of the electorate - from more than 30 percent in 2016 to nearly 40 percent in 2028 - demands that both parties cross the racial divide to succeed in the future...Hispanics will contribute the most to this gain as they overtake blacks among eligible voters in 2020 - two decades after Hispanics overtook blacks in the total population. (224)

Minority groups, professionals, and women offer a continuing opportunity for the Democratic Party. Hispanics are the most obvious focus of the three, as their outsized electoral growth will greatly affect, and possibly determine, future presidential elections. Political writer Ronald Brownstein coined the term "coalition of the ascendent" to identify specific growing voting blocs that could reinvigorate the Democratic base cultivated to the Party's advantage (Frey 225). This coalition includes Millennials, minorities, and white college graduates, especially women (ibid). Racial identification is often a predictor of party affiliation, but as Hispanics age and become assimilated into all aspects of American society, it is possible many of them will mirror the current non-Hispanic white electorate. Generational status is a notoriously fickle determination of party loyalty. Many early Baby Boomers shifted to the right politically as they aged, compelling the Democratic Party to work diligently to retain Millennial and minority support over the long term (Frey 226). 


\section{The Eventual Democratic Majority?}

Over the last two decades, social scientists and pundits have argued that the emerging democratic majority will determine national and state elections. The 2016 presidential election demonstrated that a majority Democratic electorate, while evident in the popular vote results, continues to remain elusive in Electoral College results. Judis and Teixeira (2002) argue that the Democratic majority that is apparent in modern presidential elections began to emerge in the mid-1990s and featured three main groups of supporters that were gaining voting power as part of the electorate: professionals (a group that had previously been supportive of the Republican Party), women (who had once been disproportionately Republican), and minority voters, including blacks, Hispanics, and Asians (who became solidly Democratic over the course of the 20th century, while simultaneously expanding from a tenth to a fifth of the voting electorate from 1972 to 2000) (4). Judis and Teixeira (2002), in their analysis of the emerging Democratic majority, argue that modern Democrats represent the "transition from urban industrialism to a new postindustrial metropolitan order in which men and women play equal roles and in which white America is supplanted by multiracial, multiethnic America" (6). This transition is underway in changes to the workplace, to the American value system, and to geographic shifts within the nation (ibid). The modern Democratic Party, after the transition in the 1990s, emphasizes progressive centrism that captures a diverse coalition of groups and communities.

According to Frey (2014), Hispanics have favored Democratic candidates, since 1980, between a range of 56 to 71 percent (218). Anomalies have occurred, in which the 
Democratic candidate only receives slightly more than half of the Latino vote. In 2004, John Kerry only secured 58 percent of the Hispanic vote, while Republican candidate George W. Bush received an unprecedented amount of Latino support; it was the narrowest margin of the Hispanic vote for Democrats in 32 years (Frey 219). Bush supported initiatives that his strategists thought would appeal to Hispanic voters, including education and immigration reform (Frey 224). Frey (2014) states that these initiatives, supported by Bush, received far less emphasis in the subsequent Republican presidential runs of McCain and Romney in 2008 and 2012, respectively (ibid). He further asserts that such initiatives are likely to be revisited by the Republican party in the future as they attempt to court minority, especially Hispanic, voters (ibid). Analysis of Donald Trump's 2016 victory may elucidate whether future emphasis, by the GOP, on lobbying Hispanic voters is necessary or even possible, as demographics ensure that nonwhite voters' power at the polls will only continue to increase in the coming decades.

Minority voters, but particularly Hispanics, represent an undeniably growing electorate that will impact future elections. The Hispanic electorate has yet to prove decisive in a presidential election, as Judis and Teixeira (2002) predicted more than 15 years ago, but the demographic change is evident. If conditions in the U.S. remain the same (i.e. no major anti-immigration policies, no U.S. laws that effectively suppress the Hispanic vote nationally), the Hispanic electorate is poised to ensure Democrats enjoy a majority across the country that will undoubtedly affect presidential elections. The 2016 presidential election demonstrates, though, that this may take several more election cycles due to low 
turnout among Hispanic voters and mobilized white voters reacting to demographic shifts in the U.S.

\section{Political Participation and Mobilization of Minority Voters}

Various analyses of political participation and mobilization of minority voters demonstrate the barriers these electorates face and the techniques that encourage their involvement in the democratic process. Crotty's (1991) compilation of analyses of political participation and American democracy evaluates various factors that contribute to voting. Uhlaner argues that discrimination of certain groups, namely minorities, can lead to fear, which in turn discourages voting (141). Voter identification laws and other targeted tactics of oppression, scare minority voters and hamper turnout in political elections. Minority groups with lower socio-economic statuses are also less likely to vote due to a lack of political social capital. Junn states that per the work of Verba and Nie (1972) the standard socioeconomic model of participation contains two fundamental factors.

Higher status individuals have a greater stake in politics, and they act to protect and advance their interests. People with higher socioeconomic status also live and interact with others like them who are active in politics. Through this experience, they develop the civic orientations that lead them to participate. (195)

Minorities with fewer resources are less able to capitalize on such connections and experiences. Their lack of interaction with others who are active in politics gives them little basis to protect and advance their own interests and provides no obviously recognizable incentive to participate in the political arena. Junn ultimately concludes that political participation and political knowledge are indelibly linked, and even have a reciprocal rela- 
tionship (208-209). Political knowledge naturally affects voting patterns, and vice versa, as individuals learn the importance of their participation in the democratic process.

Affigne (2000) states that Latinos' electoral participation rates declined steadily and were at their lowest point since the mid-1970s (when national census data on Latino voting participation was first collected) (525). Turnout among Latinos has always been low. Affigne (2000) finds that in 1996, "barely one-third (36\%) of adult latinos were registered to vote, and just over one-quarter (27\%) actually cast ballots for president, a figure well below comparable rates for blacks and non-Latino whites" (ibid). He further contends that citizenship was not wholly to blame. While 40 percent of Latino adults are not U.S. citizens, accounting for some of the discrepancy in turnout, "the voting gap between Latinos and whites persists even when only adult citizens are counted" (ibid). In 1996, Latino U.S. citizens voted at 44 percent, while white U.S. citizens voted at 61 percent (ibid). Lack of participation and political knowledge in Latino communities begs for mobilization efforts that encourage voter turnout that is on par with their fellow U.S. citizens.

Jackson (2011) finds that Latino voters respond positively to targeted mobilization, as well as contextual factors (i.e., living in majority-minority Latino districts, and the option of Latino candidates on the ballot) (692). If the Democratic Party finds targeted mobilization effective, it may contribute to a decisive Hispanic voting bloc in 2020 or 2024, sooner than current turnout rates suggest.

Collingwood et al (2014) outline a theoretical framework, "cross-racial mobilization", to explain and interpret actions by candidates and voters of different racial groups 
(633). The political communications between these diverse groups can be an attempt to connote concern and may even help to bridge social, cultural, and political barriers that are evident between candidates and voters in certain communities (ibid). The authors' use the term "cross-racial mobilization" to describe their framework that aims to elucidate the rationale behind candidates' decisions to incorporate positive or negative policy stances toward Latino voters (ibid). The authors also evaluate the outreach and mobilization techniques implemented by candidates focused on Latino voters and communities (ibid). They attempt to better understand how and why voters perceive certain candidates favorably or unfavorably based on these criteria (ibid). Collingwood et al (2014) build upon earlier work by Fraga and Leal (2004) who argue that, given certain conditions and particular motivations (under the economic or Downsian model), both Democrats and Republicans will actively court Latino voters (635).

In their analysis of the 2012 presidential election, Collingwood et al (2014) find that Latino-oriented variables operated in the direction anticipated by the authors (641). They contend that second- and third-generation Latino U.S. citizens were far more likely than first-generation Latino U.S. citizens to vote for Romney, the Republican candidate (ibid). Their finding is congruent with theories of assimilation and accumulation, "which intimate that immigrants become more like the general population the longer they and their off-spring reside in a country" (ibid). Additionally, the authors find predictable variable outcomes for the standard demographic and religious factors (ibid). They conclude that younger Latinos supported Obama, while Protestants and born-again Christians were less supportive of Obama compared with other Latinos; also, Catholicism was not a de- 
fining variable for supporting either candidate and poor Latinos were more likely to support Obama than Romney (ibid). Interestingly, the authors recognized gender and education to be statistically insignificant in terms of voting patterns (ibid).

Predictably, Latino voters who viewed Obama's policy statement favorably were more likely to support him and the same was also true for Romney (Collingwood et al. 641). However, their respective constituencies within the Latino voting bloc are not equal. Notably, the "Obama policy variable is overall more impactful because 58 percent of respondents said his stance makes them more supportive of Obama, whereas just 7 percent of respondents said the same about Romney" (ibid). The authors concluded that this finding demonstrates that pro-Romney Latino voters are "only the truly hardcore", whereas Obama garnered the support of a majority of Latino voters (ibid). Latino voters obviously responded positively to Obama's campaign and policy prescriptions, as well as his outreach efforts. Most of Romney's outreach efforts, with respect to the Latino community rang hollow, particularly his poorly executed Spanish language television advertisements. When asked whether Obama or Romney cared about the Latino community or if they were hostile toward it, 66 percent of Latino voters said Obama cares, whereas only 14 percent said Romney cares (Collingwood et al. 642).

Collingwood et al (2014) cite an analysis by political scientist Gary Segura (2012) of the 2012 presidential election. Segura (2012) finds that for the first time in U.S. history, the Latino vote was nationally decisive (Collingwood et al. 642). He contends that "the margin of Latinos provided for Obama exceeded the overall margin he won by, suggesting that if the Latino vote had not been mobilized, Obama would have lost" (ibid). 
This historic development in U.S. presidential elections points to a future determined, at least in part, by Latino mobilization and support. The 2012 election demonstrated that the Hispanic voting bloc can be mobilized and energized as it continues to grow in order to alter the balance of power and determine presidential elections. While Obama's share of the 2012 vote declined from 2008 in nearly every state and among the majority of demographic groups, Latinos' support increased and were one of the groups most responsible for tipping the scales in favor of Obama (ibid). While increased immigration and the polarization of policies concerning minorities may send white voters toward the Republican Party, outreach and mobilization efforts focused on growing minority communities may help stem the loss Democrats feel from alienated, older white populations. Even if the Hispanic vote did contribute to Obama's 2012 win, it did not ensure victory for Clinton in 2016. The Democratic Party must not only continue to mobilize Hispanic voters, but also should be realistic about the electorate's current decisive power in national elections.

Mobilization of minority populations not only requires policy stances that are in line with their specific community values and interests, but also an attractive candidate image that compels politically and personally. Nicholson et al (2006) find, in their analysis of political knowledge and issue voting among the Latino electorate, that if minority voters "form political judgements on other considerations such as candidates" image or political symbolism, they are more likely to then vote contrary to their policy preferences" (259). The generally low levels of political knowledge within the Latino population in the U.S. could further contribute to voting based on personality rather than policy (ibid). Latinos' low levels of income and education likely correspond with low infor- 
mation levels, political attention, and sophistication (Nicholson et al. 260). As Taylor (2014) similarly argues, low political knowledge is compounded by lack of citizenship and foreign-born status, which deprives many Hispanic children and adults of American political socialization and U.S. civics education (a requirement for children raised in the U.S.) (ibid). Verba et al (1995) find that Latinos score "the lowest of all groups on political information, interest, participation, efficacy, and strength of partisanship compared to African-Americans and non-Hispanic whites" (ibid). If either major political party makes a coordinated effort to court Hispanic voters, mobilization efforts will require increasing political knowledge and generating political networks within Latino communities.

Nicholson et al (2006) state that given minorities' lower political knowledge, it is no surprise that the most politically knowledgeable Americans tend to be well-educated middle-aged white males who enjoy access and resources that facilitate their political engagement (260). The authors argue that due to low political information levels among Latinos and the foreign-born, Latino activists' claims during the 2000 presidential election that Latino voters are "concerned more with issues than candidate-specific appeals or symbolic politics" are largely unsupported by the data (Nicholson et al. 261). It is more likely that a lack of political knowledge lends itself to the reality that Latinos fail to include many policy issues in their decision making calculus (ibid). The authors state that they are aware of only one study that attempts to examine this question of symbolism versus policy centered voting among Latinos (ibid). Abrajano's 2005 study of the effect of "education on Latino voters' responses to symbolic cues...examines the effect of issue positions on vote choice" (ibid). Abrajano, though, tests each of these variables in sepa- 
rate models and stops short of including "symbolic and issue-based effects in the same model" (ibid). The authors' study illuminates the importance of symbolism to the Hispanic electorate.

Nicholson et al (2006) evaluate, in their analysis of political knowledge and issue voting among the Latino electorate, the "degree to which Latinos are issue voters, or whether partisan identity, the likability of candidates, and the symbolic appeal of Spanish-language usage overwhelm issues in shaping their electoral preferences" (268). The authors find that the answer to their consequential question largely depends on the political information or the political knowledge possessed by individual voters and communities (ibid). Obviously, voters across all levels of the political information spectrum use party affiliation and candidate likability when determining their support of a specific candidate (Nicholson et al. 269). What was interesting, though, about the authors' study, was that when "compared to politically knowledgeable voters, low-information voters appeared to rely more heavily on candidate likability than party identification" (ibid). This is significant for any future analysis of the Latino electorate. As Latino voters continue to have low levels of political knowledge and information, many are relying heavily on candidate personality and character traits instead of their party affiliation. The authors further contend that likability was "negatively related to identifying correctly the candidates' issue positions for low-information voters" (ibid). The Hispanic voting bloc is vulnerable to candidates who act in opposition to the Latino community's interests on either side of the aisle if they halt their evaluation of politicians at the most superficial level. This analysis begs for further research on the Hispanic electorate and new ways to mobilize and 
educate voters and communities. It also leaves open the possibility that large segments of the Latino electorate may be persuaded by a candidate's charm or character and ignore specific policy prescriptions.

In addition to the potency of candidate likability, Jackson (2011) finds that Latinos, as a whole, respond to the priming effects of news reports. Jackson (2011) argues that when someone internalizes a news report about a "particular group's political preferences and influence on an upcoming election, this serves to prime our own group identities and interests, making these considerations more salient" (694). She states that political psychologists have determined the success of priming effects evident through media exposure and ratings of presidential performance (ibid). Jackson (2011) states that the "issues that are emphasized in news reports [have] a greater impact on overall evaluations" (ibid). She finds, in her study on the dynamics of Latino political identity and vote choice, that social identification among Hispanics responds "to the experimental priming of group preferences and influence subsequent vote choice" (709). The effectiveness of priming and group identification lends an important tool to campaign organizers and strategists looking to court Hispanic voters.

Jackson (2011) also finds that the political meaning of the Latino identity is not static, and will not always favor the Democratic Party indiscriminately (712). She finds that the "political influence of group identification depends crucially on the dynamic interactions between partisanship, group identification, and political context" (ibid). The relationship between all three of these influential factors establishes an individual's political identity and voting patterns. Most importantly, for those wishing to predict influence 
of political identity, "are individual differences in group identification, combined with perceived group norms at a given point in time" (ibid). Jackson (2011) uses the partisan matching hypothesis to determine whether Latinos conform to group politicization and determines that various factors contribute to priming the Hispanic voting bloc and influencing their vote choice.

Barreto et al (2008) assessed the Latino electorate in the 2008 presidential election in order to illuminate the factors that contributed to candidates' support from Hispanics. The authors argue that Hilary Clinton commanded the Latino vote in the primary elections for three reasons: "(1) higher name recognition and support of Bill Clinton; (2) endorsements from major Latino officials; (3) vigorous outreach to, and mobilization of, Latino voters" (755). Clinton employed a winning strategy to secure the Latino electorate, but was unable to translate that into a successful presidential bid in 2008 and again in 2016. Despite her losses overall, her strategy was effective among Latinos and offers an approach that politicians will want to emulate in the future. Barreto et al (2008) use Latino Decisions data from Nevada, California, and Texas to demonstrate that gender was not a strong predictor of vote choice among most Latinos (757). Clinton's support among Hispanics, then, was not based upon her gender and can, in many ways, be recreated for future candidates in their bids for the presidency. Women in Nevada and California favored Clinton by only about 5 to 7 points, while Texas saw no difference at all; in all cases Hispanics favored Clinton by a 3-1 margin (ibid). The authors state that these "single-digit differences are marginal compared to the 20- to 30-point gender gap that persisted among white primary voters" (757). Clinton, then, capitalized on her name 
recognition and endorsements, while also conducting vigorous and targeted outreach and mobilization efforts as a successful strategy to court Latino voters who were largely unswayed by her gender.

The voting process itself has suffered in recent years, especially in terms of the accessibility of the polls to minority voters. Voter identification laws almost invariably target minority voters and discourage turnout among marginalized groups. Herrnson et al (2013) analyzed minority satisfaction with the voting process in the 2008 presidential election. They find that minority voters "generally had lower expectations about the upcoming voting process, which are informed, in part, by the greater likelihood of being asked to present an ID, of waiting in long lines prior to voting" or of having more difficulties with specific voting systems (Herrnson et al. 461). As mentioned previously, such disillusionment with the voting process can discourage minority communities from mobilizing and encouraging its members to vote. Fear is a real consequence of antagonistic voting laws and systems. The authors find that older voters possessed higher expectations than minority or younger voters, which they hypothesized was the result of many previous positive voting experiences throughout their lifetimes (ibid). Predictably, those with less to fear as they enter the voting process are more likely to engage regularly in presidential elections and subsequently have an outsized affect on which politicians are elected to represent the American public. The Hispanic electorate will prove decisive in national elections when they, as a whole, feel comfortable entering the voting booth and engaging politically. 


\section{Immigration: White Backlash}

The tensions and fissures created by immigration, especially, will amount to demographic 'growing pains' as our nation readjusts to a new normal. These tensions can have real consequences, as recent immigrants, or those conflated with recent immigrants are marginalized and maligned. Frey (2014) argues that it is often a challenge for Hispanics to spread out into new areas of the country as they are mistaken for undocumented immigrants (246). The backlash against immigration, particularly the targeting of Hispanic immigrants, has demonstrated the animosity many white Americans feel toward the demographic diversification underway throughout the nation. Frey (2014) states that since 2000, "many communities have reacted by proposing punitive immigration laws designed to restrict access to housing or employment" (ibid). Within some states, local authorities attempted to restrict access to public services, education, and voting by imposing severe identification requirements (ibid). Many of the laws specifically target undocumented immigrants, but the rhetoric used to support such legislation often signals an unwelcoming attitude toward the Hispanic community and minorities in general (ibid). Such laws and rhetoric gain more traction in the New Sun Belt and Heartland regions of the U.S. where the immigrant population, often largely Hispanic, is new and growing (ibid). As mentioned above, Hispanics also often have difficulty assimilating into these communities, due to their low socio-economic status, lack of education and limited english fluency.

Abrajano and Hajnal (2015), in their analysis of white backlash within the U.S., argue that fear and resentment toward immigrants and minorities is likely to result in ex- 
panded border enforcement, a higher migrant death rate, and further strained relations between racial and ethnic minorities and the white, often native-born, population (2). They further contend that immigration, and the fear it elicits, has the power to alter the basic political orientation of many of the nation's citizens, changing life-long political affiliations and dramatically retooling the American political calculus. Abrajano and Hajnal (2015) state that a "broad backlash could lead to increasingly strict and conservative policy making, shift the balance of power between Democrats and Republicans, and advantage rightward-leaning candidates" throughout the country (ibid). The authors examine the influx of immigrants and minorities, but focus instead on the white population's reaction to the massive demographic shift and the political reorientation it inspires. This backlash was on full display in the 2016 presidential election results.

Abrajano and Hajnal (2015) outline the scholarly consensus that party identification is the "unmoved mover" that determines many political perceptions and remains largely static throughout one's life (4). The authors test whether immigration can really lead to substantial changes in party affiliation when it is a psychological attachment that is instilled early in life and deeply ingrained (ibid). Party identification is most often impervious to change and is typically only affected by major cultural or social shifts. The entrenched nature of partisanship within U.S. politics further impacts the immutability of party identification. The two major parties in the U.S. offer distinct policies and messages on immigration. The Democrats are largely supportive of immigrants and immigration, while the Republican party is mostly opposed to magnanimous immigration policies, especially in terms of undocumented Hispanic immigrants. The stark contrast offered by 
the two parties surely influences party affiliation for those who have not solidified their orientation and is impactful enough to change some individual's support from one party to another.

In their study of the native-born white population's response to immigration and race in American politics, Abrajano and Hajnal (2015) examine the reorientation of party affiliation as a reaction to immigration and a growing minority population. The authors argue that the white population's "rapidly growing allegiance to the Republican Party points toward a very different short-term future — one that might more likely be highlighted by Republican victory than by Democratic dominance" (16). This major restructuring of party affiliation due to immigration could certainly alter the balance of power that determines presidential elections. Between 2012 and 2016, the shift of white voters to the Republican Party could have affected the electoral college in such a way as to turn battleground states in the Heartland, that Obama narrowly won in 2012, to Republican territory. Through their wisdom and understanding of immigration and the fear and resentment felt toward minority groups, Abrajano and Hajnal (2015) anticipate the 2016 presidential election and the Republican Electoral College victory.

Abrajano and Hajnal (2015) determine in their analysis that state racial context and partisanship are "clearly intertwined with one another" (140). Similar to a pattern they uncovered for policies and ideology, the presence of large numbers of Latinos appears to increase the chances that white Americans, in a certain state, identify with the Republican Party as opposed to the Democratic Party. The authors find, specifically, that all else being equal, "white Americans who live in states with a sizable Latino population 
are 5 percent more likely to identify as Republican than those residing in states with few Latinos" (ibid). Due to the fact that native-born whites are 63 percent of the U.S. population, but about 75 percent of its voters, this reorientation can have an outsized political affect on presidential elections (Abrajano and Hajnal 2). The power of this voting bloc ensures that greater support for the Republican candidate in presidential and congressional contests can be decisive (Abrajano and Hajnal 141).

Abrajano and Hajnal (2015) find that controlling for a range of other factors, living in states with large Hispanic populations was associated with a 7 percent increase in the probability of voting for a Republican presidential candidate, while moving from a large to a small Latino population is linked to a 32 percent increase in the likelihood of a voter supporting a Republican congressional candidate (141). One's local racial context is clearly a determining factor in political party support. Daniel Hopkins (2010) argues, in his politicized places analysis, that individuals' political views are likely to swing antiimmigrant when a they are faced with a "sudden, destabilizing change in local demographics, and when salient national rhetoric politicizes that demographic change" (56). The outsized impact of white voters, in these suddenly destabilized communities, on the electorate is further exacerbated by limited Latino participation in political elections. Abrajano and Hajnal (2015) state that a range of factors affect Latino participation in the electoral arena "to the point where Latinos often participate at half the rate of whites" (186). Latinos, due to their lower socio-economic statuses, have less buying power in U.S. elections and are disregarded in certain political arenas because of their limited resources. 
Abrajano and Hajnal (2015) use what they term the Latino or immigrant "threat narrative" to describe a consequential factor in American perception of Hispanics and immigrants. Latinos and immigrants are deeply affected by the pervasive negative narrative surrounding immigration that often equates undocumented immigrants with Hispanics as a whole, the majority of whom are U.S. citizens and legal residents. Abrajano and Hajnal (2015) state that the immigrant threat narrative "fuels individual fears and insecurities about Latinos and immigrants," painting Latinos in a negative light and highlighting a "host of pernicious fiscal, social, and cultural consequences to immigration" (30). The impressive growth of the Latino electorate (64\% growth between 2000 and 2008), often referred to as the "sleeping giant" of U.S. elections, and the increase in elections of Latino officials across the country (from nearly zero to over five thousand nationwide over the last 40 years), plays into many Americans' fears that Latinos and recent immigrants will continue to garner substantial power throughout the country (ibid). Many Americans are fearful of such growth due to the omnipresent nature of a threat narrative that falsely equates all Hispanics in the U.S. with undocumented immigrants, who are often demonized as impediments to national prosperity.

Abrajano and Hajnal (2015) state that nearly 50 percent of Americans are under the impression that immigrants are a "burden" or feel that immigrants "hurt the country" (31). In a nation of immigrants, such statistics are startling. The threat narrative purported and perpetuated by the media, and politicians looking to capitalize on demagoguery, surely influences the image many Americans have of recent immigrants and Hispanics. Over 60 percent of Americans stated that they are concerned that undocumented immigrants 
are "putting an unfair burden on U.S. schools, hospitals, and government services" (ibid). The majority of Americans' belief that a slew of undocumented immigrants are traversing our nation's borders to take advantage of government funded social services demonstrates the alienating effect a threat narrative can have on millions of people. Abrajano and Hajnal (2015) report that a stunning 87 percent of Americans are "concerned or quite concerned that immigrants 'making low wages might make U.S. employers less willing to pay American workers a decent wage"' (ibid). Connections drawn between economic and social ills and immigrants vilify low-wage workers, while those who benefit the most, business owners who use such workers, are generating an economic net benefit for the nation at the expense of low skilled laborers, according to George Borjas (2016). U.S. immigration policies that embrace immigrants and societal acceptance of such immigrants are less likely when nearly 70 percent of Americans prefer to move in the direction of stricter enforcement of illegal immigrants rather than moving in the direction of integration into American society (Abrajano and Hajnal 31).

Backlash from the majority of Americans toward immigrants, who choose animosity instead of acceptance, is based on incorrect impressions about immigrants in the U.S. The majority of Americans (61 percent) believe that most current immigrants are in the U.S. illegally (Abrajano and Hajnal 32). Abrajano and Hajnal (2015) state that in "almost every survey that has asked about 'illegal immigration' in the last decade, an overwhelming majority of Americans—anywhere from 80 to 95 percent—view it as a 'very serious' or 'somewhat serious' problem” (ibid). Americans' anxiety regarding immigration is evident, pointing to an effective national narrative and media obsession that 
vilifies immigrants in the U.S. Americans are decidedly split on immigration, with each major political party staking out distinct and opposing positions, offering voters a clear choice on U.S. immigration policy. Immigration also permeates many other political and societal issues, further dividing Americans due to their political opinions.

Abrajano and Hajnal (2015) argue that a backlash against immigration, especially among whites, may persist only to a certain point at which a sufficient concentration of Latinos will alter the electorate and may end the establishment of anti-minority policies in their communities (186). In local, state, and national communities, this threshold, once reached, allows minorities and immigrants to fight back against a legislative and even cultural backlash (ibid). Abrajano and Hajnal (2015) ultimately contend "that the growth of the immigrant population over the last thirty years, combined with the news media's reliance on the Latino threat narrative, work together to fuel concerns over immigration" (202). This insidious combination results in greater support for the Republican Party and its candidates, especially among white Americans (ibid). Abrajano and Hajnal (2015) determine that a "preference for more conservative policies, and a shift in heavily Latino states toward policies that target and often punish the disadvantaged segments of the population" are a direct result of increased immigration, a pervasive immigrant, and particularly Latino, threat narrative, and an undeniable fear of a growing Latino electorate within the U.S. (ibid). Trump exacerbated these tensions with his insidious rhetoric on the campaign trail that fueled the mobilization of many white Americans. A growing Hispanic electorate was still no match, in 2016, for a fearful and resentful white electorate with a higher rate of turnout. 
Scholars have contributed literature and analyses regarding the growing Hispanic population, white backlash against minorities, low voter turnout among the Hispanic electorate, and mobilization techniques to encourage minority turnout. The relevant scholarship relating to the Hispanic electorate and U.S. presidential elections fails to thoroughly explain the multitude of factors that hamper the Hispanic electorate's potentially decisive nature. This thesis outlines how Trump's specific rhetoric mobilized white voters in unprecedented numbers, demonstrating the efficacy of the white backlash technique when paired with a bombastic and incendiary candidate. The work also demonstrates the demographic and electoral changes occurring within critical swing states that will determine a new Electoral College calculus in light of the growing Hispanic electorate evident in Florida, Colorado, Arizona, and Texas (among others) during and after the 2016 presidential election. A review of the structural and individual factors that retard the effectiveness of the Hispanic electorate in national elections explains why the emerging Democratic majority failed to elect a Democratic candidate for president in 2016. This thesis also demonstrates why the next presidential elections (i.e., 2020 and 2024) may demonstrate a continuation of an inhibited electorate. The Hispanic population's and electorate's growth in the U.S., if current trajectories continue in a similar vein, is inevitable, but their decisive nature in presidential elections is diminished. Several election cycles could potentially erase some of the impediments that inhibit the Hispanic electorate as political, social, and cultural changes occur due to an undeniably powerful Hispanic population that surpasses important thresholds nationally and in critical swing states. 


\section{Chapter Two: The 2016 Presidential Election}

Chapter one outlined the relevant literature regarding the growing Hispanic population and electorate, elucidating many theories regarding the Hispanic electorate that fail to explain the results of the 2016 election and possibly those in 2020 and 2024. The Hispanic electorate did not ensure a decisive win for the Democratic presidential candidate, Clinton, due to structural and individual factors that inhibit Hispanic turnout and voting eligibility. Trump was also able to mobilize white, and some Latino voters, for economic, racial, gender, and religious reasons. Some of his softest supporters were economic transactional voters (as well as religious ideological voters) whose support is contingent upon Trump policies that improve their personal economic situation. These voters helped secure the presidency for Trump, in conjunction with the failure of the Hispanic electorate to effectively register and turn out. There are always a multitude of factors that determine a presidential election, but two key variables in the 2016 presidential election are white economic voters and Hispanic voters. The first factor is an unsustainable long-term contingency in future presidential races, but the latter will only continue to grow in importance and decisiveness over the next decade. The Hispanic electorate will eventually prove decisive in national elections, but it failed to determine the victor in the 2016 presidential election. The structural and individual impediments that Hispanics endure throughout the country inhibit their mobilization and turnout in the voting booth.

\section{Transactional Trump Voters}

In an analysis of the 2016 presidential election for Cook Political Report, Amy Walter argues that many of Trump's supporters were "transactional" voters. They voted 
for Trump on the basis of his statements regarding economic policies, but are not strident supporters of the candidate they voted for. Walter states that analysis of these voters demonstrates that they "could easily sour on the president if their economic livelihood doesn't meaningfully improve or Trump's promises to 'Make America Great Again' don't live up to their expectations" (2017). These soft Trump voters significantly affected the outcome of the 2016 race, proving integral to the president's win. Transactional voters, as their name suggests, voted for Trump in order to receive something in return, in this case economic prosperity. Their continued support is contingent upon the president delivering on his promises to improve their lives economically.

The National Association of Counties (NACo) produced an analysis of 2016 county economic conditions, identifying growth and recovery patterns (County Economies 2016). NACo specifically reviewed the unemployment rate, median home prices, economic output and annual changes in jobs to determine the economic conditions within each county (ibid). Interestingly, NACo "explores average wage dynamics in 2016 and the economic recovery patterns of counties that voted Democratic in 2008 and 2012 presidential election[s] yet switched to Republican in 2016" (ibid). Evident in the results is a clear and demonstrable correlation between the counties that voted for Obama and then Trump and those facing the most economic hardship. In their economic analysis, NACo found that the "counties that flipped from blue to red in 2016" endured weaker job recoveries, 56 percent of them did not even meet their pre-recession job peaks, while only 43 percent of county economies adhered to that pattern nationally (ibid). Clearly those en- 
during non-existent economic recoveries are the most frustrated with the status quo and desire improvement by almost any means.

Throughout the 2016 presidential campaign, rhetoric surrounding manufacturing and coal industry jobs, especially in the Rust Belt, drove enthusiasm for Trump, who promised conservative and moderate voters a return of lost jobs in these industries. NACo found that voters who chose Barack Obama in 2008 and 2012 were persuaded by Trump's assurances. Clearly, the communities facing the slowest recovery were interested in a different approach to their perceived economic stagnation. Rural voters, a vital base of support for Trump's victory, were the most likely to experience this economic lethargy. NACo found that "[1]arge county economies - in counties with more than 500,000 residents - have the highest rate of full recovery (41 percent)" (County Economies 2016). In stark contrast, over 75 percent of small county economies, characterized by including fewer than 50,000 residents, have still not recovered to reach their prerecession peaks as of 2016 (ibid). Of the roughly 200 counties that voted for both Obama (in 2008 and 2012) and Trump (in 2016), NACo found that the "majority are in the Midwest, in Illinois, Iowa, Michigan, Minnesota and Wisconsin" (ibid). These counties, that swung from Obama to Trump, are disproportionately mid-sized and have economies largely reliant on manufacturing and agriculture (ibid). Many of these states were critical to Trump's Electoral College win, and swung Republican by a relatively small amount of votes.

Economic analysis broken down by county demonstrates the effect real and perceived stagnation, with respect to jobs, wages and entire industries, has on community 
political opinion. Despite a widespread U.S. economic recovery, county level recoveries did not all match the national experience. Clearly, Trump capitalized on dire economic straights in midwestern and rural counties that failed to rebound from the 2008 economic recession. Walter also references an online survey conducted by Garin Hart Yang and Global Strategy Group, Democratic pollsters, at the behest of Priorities USA, a Democratic political action committee. They focused their survey on two key groups that proved decisive in the recent presidential election- -“'swing voters' who voted for Barack Obama in 2012 and Donald Trump in 2016 and 'turnout voters' who are Democraticleaning voters, including African-American and/or Millennial voters," who were energized in 2012, but failed to turnout in 2016 (Cecil 2017). Half of the "swing voters" surveyed stated that they had mixed feelings about Trump, and only 35 percent of these voters stated that they "have confidence that Donald Trump will do a good job as President" (ibid). Women, specifically white women, were a surprising loss for Hillary Clinton in the 2016 election. This survey found that non-college educated women "make up the largest proportion of Obama-Trump voters with mixed feelings about voting for Trump" (ibid).

Along with many female Trump voters, economic voters are clearly "soft" supporters of the President, as opposed to his hard-line ideological supporters. Yang and Global Strategy Group state that "[m]ore than half (58\%) of soft Trump supporters feel their income is falling behind the cost of living" (Cecil 2017). Transactional voters expected Trump to enact policies that benefitted the lower and middle classes, whether those were tax cuts or an infrastructure package. Economic struggles characterized a 
large swath of Trump supporters, and those who refused to vote at all. The pollsters found that "“[t]urnout voters"”- those who voted in 2012, but not 2016 - are disillusioned about politics, but extremely unhappy about the idea of a Donald Trump presidency" (ibid). Many did not think Trump could win and were not inspired to vote for Clinton. These voters, per the survey, struggle economically and dread spending years under President Trump (ibid). Apart from "swing" and "turnout" voters, another survey further dissected voters in the 2016 election, designating four categories to describe their distinct opinions regarding the Trump administration.

A CBS News 2017 Nation Tracker poll, undertaken by YouGov, conducted over 2,000 interviews of Americans who reported voting in the 2016 presidential election. Interviews were balanced between those who reported voting for Trump and those who reported voting for Clinton. When asked their opinion regarding President Trump, interviewees separated themselves into four groups: Believers, Conditionals, Curious and Resistors (Salvanto et al. 2017). The Believers, representing 22 percent of those polled, are the most strident supporters of the Trump administration and the policies proposed by the President (ibid). The Conditionals, also representing 22 percent of the polled body, support him, but are waiting for President Trump to deliver on his campaign promises (ibid). These voters mirror the transactional voter phenomenon, as they are economicallyfocused and "will remove their support if he doesn't 'fix the economy' for them" (ibid). Even as the economy has improved since the 2008 recession overall, these transactional voters have remained largely untouched by the recovery and are looking for someone to amend their personal economic situation. 
The CBS Nation Tracker poll found that 80 percent of the conditional Trump supporters will withdraw all or some of their support if he doesn't fix the economy (Salvanto et al. 2017). This figure demonstrates the transactional nature of their support. If the poll is truly representative, and nearly a fifth of Trump voters will withdraw their support if their personal economic situation does not improve, the Trump administration is not blindly supported by the majority of Americans. The poll labels those opposing Trump, but interested in the results he garners the Curious (ibid). The Curious, representing 21 percent of those polled, currently oppose President Trump, but "“would reconsider' supporting him if he does a good job" (ibid). These voters are largely looking for respect from the Trump administration and 90 percent say Trump will gain their full or some support if he improves the economy (ibid). These Curious voters are younger than the average polled, and are more likely to be women (ibid). Younger women, and all others represented in this category, obviously felt offended and disrespected by many of candidate Trump's comments and prospective policies. These voters, though, are also consumed by economic concerns and would be willing to support Trump if he improved their personal economic situation.

The pollsters label those firmly opposed to President Trump the Resistors. This immovable group represents 35 percent of those polled (Salvanto et al. 2017). Despite their staunch opposition, however, four in ten of the Resistors failed to turnout on election day (ibid). Their lower rate of participation than Trump's Believers certainly contributed to his 2016 electoral victory. Possibly due to this uninspiring turnout, one in ten Resistors feels "motivated" by the Trump presidency and looks to not only resist, but to 
rally around the opposition party (ibid). If Trump proves economically ineffective, especially with respect to the communities of his conditional supporters, the Curious, the Conditional and the Resistors will all be united against Trump's presidency and policy prescriptions. Transactional voters question the Trump administration's effectiveness and could prove decisive in an opposition force that weakens and fails to re-elect the President.

Mark Blumenthal, in his analysis of the 17 percent of Americans who view Trump "somewhat favorably," finds that the soft approval of these supporters extended to Trump's image as a tough outsider who could get things done, but not to his management or administrative style. Blumenthal finds that 68 percent of "those who only somewhat approve of the President say he stands up for his beliefs," while 60 percent "say he is tough enough for the job" and 59 percent say he "can get things done" (Walter 2017). His appeal to these soft supporters is clear, he seemed equipped to end the gridlock in Washington D.C., and accomplish his goals for the benefit of the American people. Blumenthal, though, also recognized Trump's shortcomings in the eyes of his soft supporters. Only 38 percent of the respondents who "somewhat approve" of the President are confident about his "ability to keep promises" (ibid). Even fewer, (34 percent), believe Trump will perform as an effective manager (ibid). These figures are reminiscent of transactional or conditional voters, who wished for change, but would only maintain their support if President Trump delivered on the policy prescriptions and economic revitalization he promised. 
His soft supporters, Blumenthal finds, are even less likely to equate their own principles with President Trump. About 20 percent of his supporters who only "somewhat approve" of him "associate qualities like empathy, shared values or inspiration with the new president" (Walter 2017). In a surprising find, Blumenthal notes that just 11 percent of “Trump's soft approvers say 'honest and trustworthy' applies to him” (ibid). Despite their support in the voting booth, these soft approvers clearly question Trump's ability to embrace the gravity of the office of the president by demonstrating an ability to provide truthful information to the American people. Walter argues that these results prove "marginally supportive Trump voters already have pretty low expectations for his ability to manage effectively or that he will share their values" (ibid). These voters, like the transactional and conditional supporters, will not approve of a President Trump who fails to deliver on his promise to destroy the status quo of political gridlock. Blumenthal argues that these soft approvers may not be interested in Trump's personal character failings, but they will not forgive an inability to end legislative stagnation (ibid). Blumenthal states that if initial legislative successes give way to stalemates to which Americans have grown accustomed, “perceptions of Trump's ability to 'get things done' may atrophy, and with it, his overall approval rating" (ibid). If the President wishes to maintain his support among this demographic, he will need to improve their economic well-being and shakeup Washington D.C. for their benefit (ibid).

Transactional Trump supporters voted for the President in a quest for economic improvement and political revitalization. Gridlock in Washington D.C. will likely prove too entrenched for a novice politician with no experience in government bureaucracy. 
Trump's limited understanding of political processes will disappoint his soft supporters who are desperate for change and wish to end economic and legislative stagnation in their struggling communities. These supporters will likely be the first to abandon Trump if and when he fails to meet the impossibly high expectations he set during the campaign. If his promises remain empty, transactional Trump voters will quickly search for a new avenue to prosperity. The white vote will eventually be eclipsed by the minority vote, due especially to the growing Hispanic electorate. As Hispanics ultimately prove they can be the decisive voting bloc that social scientists have heralded for years, no amount of white voter mobilization will be able to overshadow their voting power.

\section{White Voter Mobilization}

The Trump campaign performed the surgical task of mobilizing sufficient white voters in rural counties across the Midwest and the Rust Belt in order to off-set a growing minority electorates' support of Clinton. This impressive Electoral College strategy ensured victory for Trump and diminished the excitement surrounding the 'sleeping giant' pundits and analysts had been focused on. The Latino electorate is clearly poised to alter the political calculus of national and state campaigns in the coming decades, but Trump proved that one does not even need a third of the Hispanic vote to become President of the United States in our current political climate. His demonization of immigrants, and Hispanics specifically, gave Trump greater turnout among white voters, offsetting losses from Hispanic or immigrant voters. Trump's win demonstrated a previously untapped white vote (i.e., voters who had never voted or hadn't voted in several election cycles) that could be galvanized through a unforgiving immigration stance and economic policy 
prescriptions that Trump promised would improve their personal and their community's future, while simultaneously restoring white males to their previous stations of privilege and power.

Support among white voters proves that the failure of a projected "surge" of Latino voters against Trump is not the sole reason for his success. The "great demographic firewall" that so many pundits insisted would be decisive in the 2016 election and "safeguard progressive politics with surging population numbers" only "stands in a few states, and the biggest of them, California, New York and Texas, are already decided" (Suro 2016). Geography, not demography, was the decisive factor in the 2016 presidential election. Mobilization of extra Latino votes in predictably Republican or Democratic states only served to increase Clinton's popular vote lead, but failed to garner sufficient support in swing states to offset significant white voter support for Trump. Suro (2016) states that the "bitterest loss was dealt by the 59.5 million mostly white people who voted for Mr. Trump" because it was a "rejection [of Latinos] by their own countrymen." White voters were instrumental in the election of Trump, who demonized and alienated many Latino voters with his divisive rhetoric. Daniel Smith, a political science professor at the University of Florida, similarly argues that the election results were not due to a failure of Hispanic turnout (Gomez 2016).

In the critical swing states of Florida and Pennsylvania, Smith argues that any surge of Hispanic support could not have offset the "massive gains Trump made with white voters" (Gomez 2016). Smith states that the election wasn't won or lost with Hispanics (ibid). Instead, he asserts that it "had to do with white, suburban voters, especially 
women, breaking much more for Trump than anyone expected" (ibid). White, female voters, especially in the Midwest and the Rust Belt were instrumental in securing Trump's Electoral College victory. Many thought that Trump's personal failings and lascivious comments would be his undoing with respect to suburban white women, especially because of Clinton's historic candidacy and her status as a women's rights icon. Noel (2016) states that white women "were expected to overwhelmingly reject the prospect of a lewd, misogynistic, alleged groper-in-chief, but instead voted in President-elect Trump, throwing 53 percent of their support behind him." White American women significantly diverged from minority women voters in the 2016 presidential election. Clinton and Trump uniquely divided the country and the U.S. electorate, demonstrating a rare, and likely never repeated, voter breakdown. Many white women were persuaded by Trump's economic and social messages despite his often sexist and disrespectful actions and rhetoric.

Polling indicates stark divisions between women and men, as well as between different racial and ethnic groups within the U.S. electorate. Rogers (2016) states that the data demonstrates how "deeply divided" Americans are along these racial and gender classifications. Clinton garnered 94 percent of the vote among black women and 68 percent of the Hispanic female vote, but 53 percent of white female voters in the U.S. voted for Trump (Rogers 2016). National exit polls show that 62 percent of Latino men voted for Clinton, while Latino Decisions' election eve poll shows 71 percent and 86 percent of Latino men and Latina women voted for Clinton, respectively (Gamboa). Education further elucidates divisions within the electorate. Trump's success among working class vot- 
ers extended to women, as he received 62 percent of the vote from white women without a college degree; Clinton amassed 51 percent of the vote among white women with college degrees (ibid). This educational division is even more stark when one analyzes male voters. Trump won 63 percent of white men overall in the 2016 election, but only 54 percent with a college degree and an astounding 72 percent of white men without a college degree (ibid). White women, even those with a college degree, lent significant support to Trump in key swing states. Many were shocked by these polls that indicated Trump's misogynistic comments or past behavior did not deter a substantial swath of the white female electorate. Some explained the surprising popularity of candidate Trump with white women by pointing to the influence of his daughter Ivanka on her father and the campaign.

Petersen (2016) illustrated the phenomenon of the "Ivanka Voter" in her description of suburban white female voters who helped usher Trump into the White House. Many of these voters were not overt in their support for Trump during the campaign and hail from wealthy suburbs of major Midwest cities. Petersen (2016) states that this voter is more impressed by Ivanka than her father, a perfect antithesis to her father's lack of sophistication and class. The suburban female Trump voter does not necessarily agree with everything Trump says or even promises and describes herself as "socially moderate" (Petersen 2016). One such voter, Michelle from Rochester, Michigan, was a Clinton supporter early in the campaign and “didn't like anyone on the Republican side” (ibid). Michelle voted for Democrats in the past and supports marriage equality; she is prochoice, but does not support late-term abortion (ibid). "She likes that Trump isn't super 
religious...or a super social conservative like Ted Cruz, because she's not a particularly religious person herself" (ibid). She ultimately decided to vote for Trump because she believes Clinton is corrupt and will be a continuation of the status quo that has led to entrenched political paralysis at the national level (ibid). The impact swing voters, like Michelle, had on the 2016 presidential election is indisputable.

The sway that suburban women voters enjoy and the electoral attention they receive in every election are due to their "sheer number, but also their voting patterns" (Petersen 2016). They are consistent voters and coupled with Trump's engagement of white working class voters in swing states, who are inconsistent voters at best, he was able to solidify his Electoral College defeat of Clinton. Suburban women, a term pollsters use to describe white, 30-plus, college-educated women, "vote at significantly higher rates than their non-white, younger, non-college-educated, male peers" (ibid). Suburban white women are dependable, albeit swing, voters who do not face the same systemic disenfranchisement that many non-white, non-suburban citizens encounter in their journey to the voting booth (ibid). These white female suburban voters are often characterized as fiscally conservative, socially moderate to liberal, wealthy, and interested in maintaining their way of life (ibid). "They voted for Clinton in 1996, George W. Bush in 2000 and 2004, Obama in 2008, and Romney in 2012" (ibid). These voters appear to not have subscribed to the cult of personality that surrounded Trump and many of his supporters. An astounding, given his support from them in the voting booth, 60 to 70 percent of suburban women view Trump negatively, "a statistic that would utterly sink most candidates" 
(ibid). This apparent internal dissonance did not diminish turnout among suburban women, who either looked to Ivanka or figuratively held their nose in the voting booth.

Among the various reasons Trump was able to secure an Electoral College victory was his unique mobilization of white voters in specific states. Cohen (2016) states that "Trump mobilized white voters who few expected to vote." Additionally, Democrats failed to turnout in these states where white rural voters exceeded turnout expectations. The Democratic rule of thumb for Pennsylvania is that a strong turnout in Philadelphia will offset rural, Republican strongholds in counties across the state to ensure Democratic victory and 20 electoral votes. The 2016 presidential election disproved the conventional wisdom regarding Pennsylvania. Clinton received "more votes in Philadelphia County than Obama in 2012;" in fact, she amassed "56,000 more votes than Obama" in the Philadelphia suburbs and even won Chester County, which Obama failed to do in 2012 (Cohen 2016). Clinton "mobilized the so-called Obama coalition of affluent, collegeeducated whites and nonwhite voters" and yet, "she lost the state by 68,000 votes" while Obama "won it in 2012 by 320,000 votes" (ibid). Trump's extraordinary candidacy reversed the Democratic advantage in Philadelphia turnout "by doing what almost no political observer thought he could do and no polling showed possible: mobilizing a huge number of white rural voters" (ibid). Trump's campaign defied the pundits and demography experts by reversing growing Democratic trends just enough in specific states to clinch an Electoral College victory.

In addition to shifts from Democratic to Republican leads in moderate counties, Trump's campaign inspired higher turnout among white voters in red counties (Cohen 
2016). In red counties across the country, but especially in the Midwest and the Rust Belt, Trump outperformed Romney. While some white rural voters in Pennsylvania swung their support from Obama to Trump, in Northampton County, Clinton matched Obama's vote total from 2012, but Trump secured 12,000 more votes than Romney did in 2012 (ibid). The results in Pennsylvania underscore the affect swing voters can have in a battleground state. As Florida, Arizona, Colorado and Texas swing more Democratic due to their demography, Pennsylvania, Wisconsin and other Midwestern and Rust Belt states are becoming more Republican as their white rural and suburban voters swing to the right politically. This demographic and political evolution will dramatically alter the Electoral College calculus for candidates and strategists in future national and state elections. The Hispanic electorate across the country will eventually eclipse non-Hispanic white voters, but the pace of this change is inhibited by structural and individual factors that were on full display in this election.

\section{$\underline{\text { Review of } 2016 \text { Polling and Analysis }}$}

In addition to exit polls and surveys, Robert Suro (2016), in his analysis of the 2016 presidential election, presents an explanation for Trump's victory that closely aligns with the White Backlash theory espoused by Abrajano and Hajnal (2015). Suro (2016) argues that while Latinos did not turn out dramatically against Trump, white Americans embraced Trump's anti-Hispanic and anti-immigrant rhetoric, propelling him to victory. Trump's campaign advisors made a calculated, strategic choice to run to the right on immigration and allow their candidate to make ignorant and disparaging comments about Hispanics and immigrants. More than cause an upswell of Latino support for his oppo- 
nent, Trump's actions galvanized support among white Americans, ensuring record turnout among this shrinking demographic. Suro (2016) contends that when Trump "demonized Mexico and unauthorized immigrants, he gained more in the Electoral College by mobilizing white voters than he lost by alienating Latinos.” This calculated electoral strategy succeeded in providing enough support from white Americans, some of whom rarely participate in the electoral process, to overcome any gains made by Clinton among minority voters. Journalists and social scientists recklessly insisted that the demographic sleeping giant, referring to Hispanic minority voters, would provide a "demographic firewall" as early as the 2016 presidential election, when that reality was only evident in specific states that are reliably consistent in every electoral contest (e.g., California) (Suro 2016).

Political analysts incessantly discussed the "Trump Effect" that was "supposed to have produced a surge in naturalizations and voter registration over the past year" (Suro 2016). Analysts clearly underestimated the mobilization effect anti-Hispanic rhetoric and constant news stories about the sleeping giant that is the Hispanic electorate would have on white American voters. The perceived threat of a surge of Latino voters on election day encouraged opponents of such demographic change to turnout for Trump. This digression from conventional electoral wisdom is most evident in Florida, where in many cases Latino immigration has propelled the state and local economies to prosperity. Suro (2016) argues that Latinos face an unfortunate reality, one in which their neighbors begrudge them, promote policies that harm them and support a candidate who disrespects them. 
In a state that has vividly benefited from immigration and trade, a state where Latinos have for the most part prospered and contributed to the prosperity of their neighbors, white voters mobilized to elect a candidate who would angrily erase everything Latinos represent. No one else suffered that kind of defeat on Tuesday. (Suro 2016)

Suro (2016) references Election Day, 2016 to mark a defining moment in white/Hispanic relations in the U.S. The animosity evident in Trump's campaign speeches and among his supporters demonstrates a fear and demonization that points to a larger, and more deeply rooted, sentiment within the country. While expert pollsters dispute the Latino support for Trump, the galvanization of white support for Trump is undeniable.

Exit polls of the 2016 presidential election, a rough measure of voter turnout, found that Latinos accounted for 11 percent of the votes cast on election day, at parity with their turnout in the 2012 election (Suro 2016). Clearly, growing demographics increased the raw numbers of Latinos voting in the 2016 election, but exit polls fail to demonstrate any surge in Latino turnout. Latino Decisions, a Latino opinion research company comprised of research scientists (some of whom worked for the Hillary Clinton campaign in 2016), conducted thorough polling throughout the election, with particular emphasis on their Election Eve Poll (Sanchez and Barreto 2016). Members of the Latino Decisions team argue that exit polls are unrepresentative of the U.S. Latino electorate as they procure results from a small sample of precincts without matching the census for correct geographic dispersion of Latino voters (ibid). Latino Decisions offers a "random statewide sample of all Latino voters across each state" and their survey is "available in English or Spanish from point of first contact" (ibid). Latino Decisions polling indicated that "high levels of Latino enthusiasm about voting were driven largely by fear of a Trump victory" (ibid). Their Election Eve Poll finds that " 55 percent of Latino voters 
stated that Trump was 'hostile' toward Latinos or Hispanics and 29 percent said he 'did not care too much' about Latinos" (ibid). Their results, as opposed to traditional exit polling, indicate a "Trump effect" among Latino voters who felt victimized by his campaign rhetoric.

Only 18 percent of Latino voters in 2012 viewed Romney as "hostile," but nearly twice as many (56 percent) as Trump said Romney "did not care" about Latinos (Sanchez and Barreto 2016). Latino Decisions estimated that 13.1 million to 14.7 million Latinos turned out to vote in the 2016 election, an increase from the 11.2 who voted in the 2012 presidential election (ibid). Latino Decisions further concluded that Clinton received "a record-high 79 percent to 18 percent for Trump, with 3 percent voting for one of the third-party candidates" which outpaces the 75 to 23 percent Obama advantage over Romney in 2012 (ibid). Latino Decisions' Election Eve Poll may overstate Clinton's support and Trump's shortcomings among Latinos. Harry Enten (2016) of FiveThirtyEight states that a "detailed look at pre-election polls and actual election results from counties with large Latino populations suggests that Trump probably did no worse than Romney among Latinos, and probably did better.” Further analysis of Hispanic Trump voters is below. Some polling firms argue that exit polls are superior to a pre-election polling because exit pollsters do not need to make assumptions about who is most likely to vote, as they only interview individuals who have just physically voted (Enten 2016).

Enten (2016) states that Latino Decisions polls people in part by "identifying individuals with common Spanish surnames; that means they may miss Latino voters who don't have Latino-sounding names, who tend to be more Republican-leaning." Apart 
from the assumptions required to conduct Latino Decisions' polls, 18 of the 24 U.S. counties with at least 75 percent Latino residents of their voting-age population voted at lower rates for Clinton than they did for Obama (ibid). Clinton did outperform Obama in certain larger urban counties, but she underperformed Obama in "five of the six counties where Latinos make up at least 90 percent of the voting-age population" (ibid). Clinton's margin of victory in the counties were she did outperform Obama rarely matched the margin among Latinos that Latino Decisions found in their Election Eve Poll (ibid). Exit polls, in their failure to include sufficient Spanish language interviewers and random sampling polling, likely underreported Clinton's support among Hispanic voters. Latino Decisions, in their polling of likely voters prior to election day with a specific focus on Latinos with common Spanish surnames, may have inflated Clinton's support among Latino voters. A discrepancy in predicted versus actual turnout of Latino voters may be explained by the differential turnout on Election Day among Democrats and Republicans (Ramakrishnan 2016).

The official media-sponsored exit polls reported that nearly a third (29 percent) of Hispanic voters supported Trump, two percentage points higher than Mitt Romney secured in 2012 (Kilgore 2016). Trump's performance among Latinos, compared to Romney's, could be explained by Trump's appeal to working-class voters. Romney had a conservative anti-immigration stance like Trump, but was bogged down by his rich, out-oftouch image that offended many who were economically debilitated by the Great Recession (ibid). Despite Trump's wealth, he connected with working-class voters desperate for economic improvement, white and Hispanic. Additionally, minority-party voting, for 
Gary Johnson and Jill Stein, likely contributed to Clinton's fall to 65 percent of the Latino vote, behind Obama's 67 percent in 2008 and 71 percent in 2012 (ibid). Clinton clearly won a majority of Latino voters, but the degrees of the victory matter, as demographics evolve within the U.S. and social scientists look to predict how such shifts will affect future electoral contests.

The discrepancies in polling results of the 2016 presidential election can never truly be reconciled, but the implications of these differing results are readily apparent. Trump received either a third or less of the Latino vote and still ascended to the presidency by way of an Electoral College win. Clearly the Hispanic voting bloc is not crucial to a presidential win in our current electoral climate and a 40 percent floor of Hispanic support is not necessary to win a present-day electoral victory (Dinan 2016). Some experts argue that if Clinton had maintained support in Midwestern and Rust Belt states, "the story of the election would have been how Latinos powered Mrs. Clinton to victory by helping her keep Colorado, Nevada and Virginia blue" (ibid). And some still argue that the surge in Latino support is real and will continue, eventually turning Arizona and Texas competitive in future elections (ibid). Trump was a unique candidate who was able to form an unusual coalition and mobilize white lower and middle class voters who felt left behind by a globalized economy. Turnout among Democrats in Midwestern and Rust Belt states for Clinton failed to match Obama's galvanization in 2008 and 2012.

Trump found a narrow path to victory according to Frank Sharry, executive director of America's Vote (Dinan 2016). Sharry argues that if "one assumes that Trump runs for re-election in 2020, I think he's going to have a very difficult time repeating the mira- 
cle. And it was a miracle" (ibid). A confluence of factors created the electoral landscape that enabled a Trump victory. While an analysis of all elements to an election is important, highlighting those that are most likely to affect future elections is vital to political prediction and societal evaluation. In the current U.S. political climate, Hispanics cannot be considered a singularly decisive or monolithic group. If exit polls are even remotely accurate, the 2016 presidential election proves that Republicans can still garner close to 30 percent of the Latino vote while simultaneously taking a strictly conservative stance on immigration, "puncturing the conventional wisdom that Hispanics are largely single-issue voters" (ibid). Hispanic voters will continue to grow as an electorate over the coming decades, transforming the electoral map and altering the political landscape. Swing states are illustrative of the changes already occurring within the U.S. electorate that will surely prove decisive in future elections, even though they are not yet determinative.

\section{$\underline{\text { Hispanic Trump Voters }}$}

Hispanic voters' policy preferences and ideological stances are as diverse within their voting bloc as all American voters are in relation to one another. Hispanic voters chose Trump for various reasons including immigration policy, religious convictions, and the promise of economic welfare. Some Hispanic Trump voters oppose illegal immigration and begrudge those who enter the U.S. illegally when they or their family members engaged in the costly, tedious legal immigration process to enter the country. Others were persuaded by Trump's promises to improve the economy and create jobs for those suffering in rural counties or those losing working-class jobs to technological advances and 
globalization. Some Hispanic Trump voters disagreed with many of his policies or were disgusted by his rhetoric, but chose to vote for him based on their religious or social convictions (e.g., abortion, gay marriage). Rural Hispanic voters mirrored rural white Trump supporters in many ways. Cadava (2016) finds that "many rural Southwestern counties with large Hispanic, predominantly Mexican populations, moved in Trump's direction." Trump did even better than Romney did in these largely Hispanic rural areas and Hillary did worse than Obama did in 2012 (ibid). These largely Hispanic rural counties mirror the voting patterns in similar counties in Pennsylvania, Ohio, Michigan, and Wisconsin (ibid).

Clinton likely suffered politically in rural counties for her comments regarding coal miners in the Rust Belt and her campaign's seemingly dismissive approach to rural areas throughout much of the country. Trump's economic and social message appears to resonate with rural Hispanic voters who, experientially, likely have much in common with rural Midwestern voters looking for economic relief. Cadava (2016) argues that Latino Decisions' precinct polls focused on “overwhelmingly Hispanic precincts in more urban areas, not the rural communities that tell a different story." Clinton failed to gain the same level of support that Obama did in dozens of rural Southwest counties in 2012 (Cadava 2016). The 2016 presidential election divided rural and urban voters more starkly, in some cases, than different racial or ethnic groups. The economic and social upheaval of the 21 st century adversely affected many rural Americans. Valdes (2016) discovers that for Florida's rural Latino population, Trump was speaking to their fears and hopes about the future. Roberto Rodríguez Tejera, a Spanish-language talk-radio show host in 
South Florida argued that rural Hispanic voters, much like their rural white counterparts, are frightened by "the specter of feminism, Muslim immigrants and L.G.B.T. rights" (Valdes 2016). Tejera further states, "[f]or many Hispanic Americans, the cultural changes of the past 15 years have been very hard" and that Trump, for many, "is a return to the mother's womb" (ibid).

Differing cultural heritages, economic situations and residential communities ensures divergent political opinions among Hispanics in the U.S. While Trump's alienating anti-immigrant and anti-Mexican rhetoric was disparaging and inconsiderate, many Hispanics agreed with his policies and delighted in his promises of an America that harkened back to the 20th century. Gomez (2016) interviewed various Hispanic Trump supporters who exemplified this emphasis on policies over rhetoric. Denise Galvez, a CubanAmerican co-founder of "Latinas for Trump" argued that political pundits and analysts “focused too heavily on Trump's bombastic rhetoric and ignored the quiet, growing share of the Hispanic electorate that was willing to understand his platform" (Gomez 2016). Galvez asserted that she never believed Trump wanted to "deport all 11 million undocumented immigrants or that he felt all Mexicans were rapists and drug dealers" (ibid). Those who argued that Trump's comments assured Clinton an unprecedented majority of Hispanic supporters that would propel her to victory clearly failed to recognize the importance of Trump's policy platform to many Hispanic voters.

Galvez concedes Trump's faults, but argues that "everybody took him out of context" (Gomez 2016). As a founder of "Latinas for Trump" Galvez chooses to separate what he says about some Mexicans or immigrants from his feelings regarding Hispanics 
overall. She argues that the way in which many extrapolate "that he hates all Mexicans and he hates all Hispanics and he hates all immigrants is absolutely ridiculous" (ibid). Divisions within the Hispanic community itself are evident in many Latinos' attitudes about Trump's proposed border wall with Mexico. Valdes (2016) states that nationally, "Pew Research Center reports that roughly a quarter of Hispanics favor building that big, beautiful wall." Seemingly incomprehensible attitudes of Hispanics toward their fellow Hispanics are partially explained by the affect undocumented immigration can have on Hispanic Americans. Valdes (2016) argues that "Mexican[s] or Central Americans who cross the border without papers are more likely to take jobs from their compatriots than from non-Hispanic whites." It is also often the case that Hispanic American citizens and legal residents are the victims of radicalized nativism and ethnic "distancing" by those who do not distinguish between legal and illegal residency (Valdes 2016). Backlash, not just by non-Hispanic whites, but also by legal Hispanic residents, against undocumented immigration certainly contributed to Trump's victory, especially within rural counties of consequential swing states.

Valdes (2016) interviewed Cuban-American Floridian political consultant and pollster Fernand Amandi who described the reasons eight of his relatives voted for Obama in 2012 and then five of those relatives voted for Trump in 2016. Amandi argues that these relatives regarded Trump as a "hand grenade to a political system that they saw as being ineffective and out of touch" (Valdes 2016). Those who wanted political change to disrupt Washington D.C. found their candidate in Donald Trump, despite his rhetorical and personal failings. Apart from these disruptors, who may have been new Republican 
voters for this specific election, are the Hispanics who vote the Republican Party ticket every election. This "floor" of Hispanic Republican voters is critical to stemming the minority gains that are slowly growing within the Democratic Party. Despite Hispanics' poor turnout, demographics suggest that eventually (i.e., within the next 20 years), the growth of the Hispanic electorate will prove decisive in presidential contests for Democrats. However, the 2016 election demonstrates that in the near future Hispanics will not necessarily be as consequential a voting bloc as political pundits and social scientists have been predicting.

Turnout and voting eligibility are certainly factors in Hispanics' slow ascendence into the political forefront, along with values widely shared throughout the Hispanic community. In the last three election cycles, roughly 30 percent of Hispanics voted for a Republican candidate for president. Republican's failure to embrace immigration reform and truly demonstrate respect and inclusivity has not diminished this "floor" of Hispanic voters. Khalid (2016) found that for some voters, like 23-year-old Joseph Adorno, their vote was less about Trump and more about party loyalty. Adorno stated: 'I guess it's more about the Republican Party in a way" (Khalid 2016). Adorno was more concerned with those the U.S. President is empowered to nominate, including judges (ibid). Conservative Supreme Court justices and conservative federal judges were vitally important to some Latino voters. For many Catholic and evangelical Latinos in the U.S., like 26year-old Iris Chavez from El Salvador, abortion laws are their top priority ("Dream in Blue" 2016). In reference to a Planned Parenthood-like women's clinic Chavez said: "If we can close that one clinic...we can set fire to the nation" (ibid). Chavez's belief that 
abortion is murder steers her political preferences as it does for so many conservative, Christian Hispanics.

Conservative, Christian values play an often decisive role in Hispanics' political calculus in U.S. elections. Pastor Mario Bramnick, a Trump surrogate from South Florida, argues that for most Latinos, "not only Hispanic evangelicals, family values are important, social values are important" (Khalid 2016). He further argues that there was "this real skew toward religious liberties in the last eight years of the Obama administration" and that Trump told those worried about religious liberty that under his presidency one would have "“a right to speak like everyone else" (ibid). Trump's insistence that Democrats were threatening Christians' religious liberties only served to stoke the fears simmering across the country, especially in rural counties. While many did not agree with his bombastic, and at times offensive, rhetoric, in a race where only two candidates had a realistic chance of winning, he represented the Pro-Life, conservative Christian wing of American politics. For those who prioritize those values above all else, Trump was the only, if not ideal, option.

Dianna Náñez (2016) interviewed two avid Trump supporters who, among other reasons, gave faith as their top political priority. Mercy Stika and Nancy Poindexter, female Hispanic Trump voters, are self-described "Bible-believing Christians" who support the president (Náñez 2016). For many Hispanic evangelical Christians in the U.S., national security and fear of undocumented immigrants also pervade their political calculation. Náñez (2016) quotes Poindexter to accurately elucidate this argument among Trump supporters. 
"We have people that are coming into our country, we don't know where they came from, what they're about and they are just here to harm us... They're not here to want to learn our culture or beliefs. They're wanting to change America, change us and want to make it theirs. Well, if that's what they want, they need to stay where they came from and we need to secure our borders." (Náñez 2016)

Indeed, the border wall that he promised throughout the 2016 campaign is not wholly reviled by the American Hispanic community. In comparison to African-Americans, who oppose the border wall with Mexico by 82 percent, only 68 percent of Hispanics in the U.S. are against it (Noel 2016). A Mexican-American truck driver in his late fifties, interviewed about his support for Trump, expressed his frustration with those who cross the U.S.-Mexican border illegally and believes a wall would significantly stem the problem: "They should build the damn wall or watch [American citizens] rise up in arms...Both psychologically and physically the wall works, and I can't wait to see Trump come through on his promise" (ibid).

This Trump supporter, like many Hispanic Trump voters, begrudges those who illegally enter the U.S. and cause what he believes is a drain on the system. The wide range of opinions within the Hispanic voting bloc is often lost under generalizations and overly simplistic terms. Noel (2016) contends that in her interviews with Mexican-American voters on the border, "it became clear to me that [L]atino voters have been largely misunderstood, and projections were not representative of the rainbow of opinions that Hispanic individuals hold, nor who they consider their vested allies to be." Identity plays an indelible role in Hispanic-Americans' political positions and preferred policy prescriptions. The Mexican-American truck driver stated in his interview that he is "an American first," and also "a patriot" who served in the U.S. Army (Noel 2016). His identity and experi- 
ences dictate his political and personal ideology. He argues that he shouldn't be pigeonholed into a certain belief system, nor should his support of a particular candidate be presumed simply because of the way he looks: "I'm an American, and [I] vote for my country's interest" (ibid). As discussed, many Hispanic-Americans resent being conflated with undocumented immigrants who are forced to live in the shadows of society. Only 78 percent of Hispanic voters, as opposed to 82 percent of black voters, believe that unauthorized immigrants should be able to apply for legal status in the U.S. (ibid). The divide within the Hispanic voting bloc will persist in future elections and represents the limitations of our taxonomy and terminology for a consistently diversifying electorate.

Figure 2-United States: Hispanic or Latino Origin Population Percentage, 2013 by State

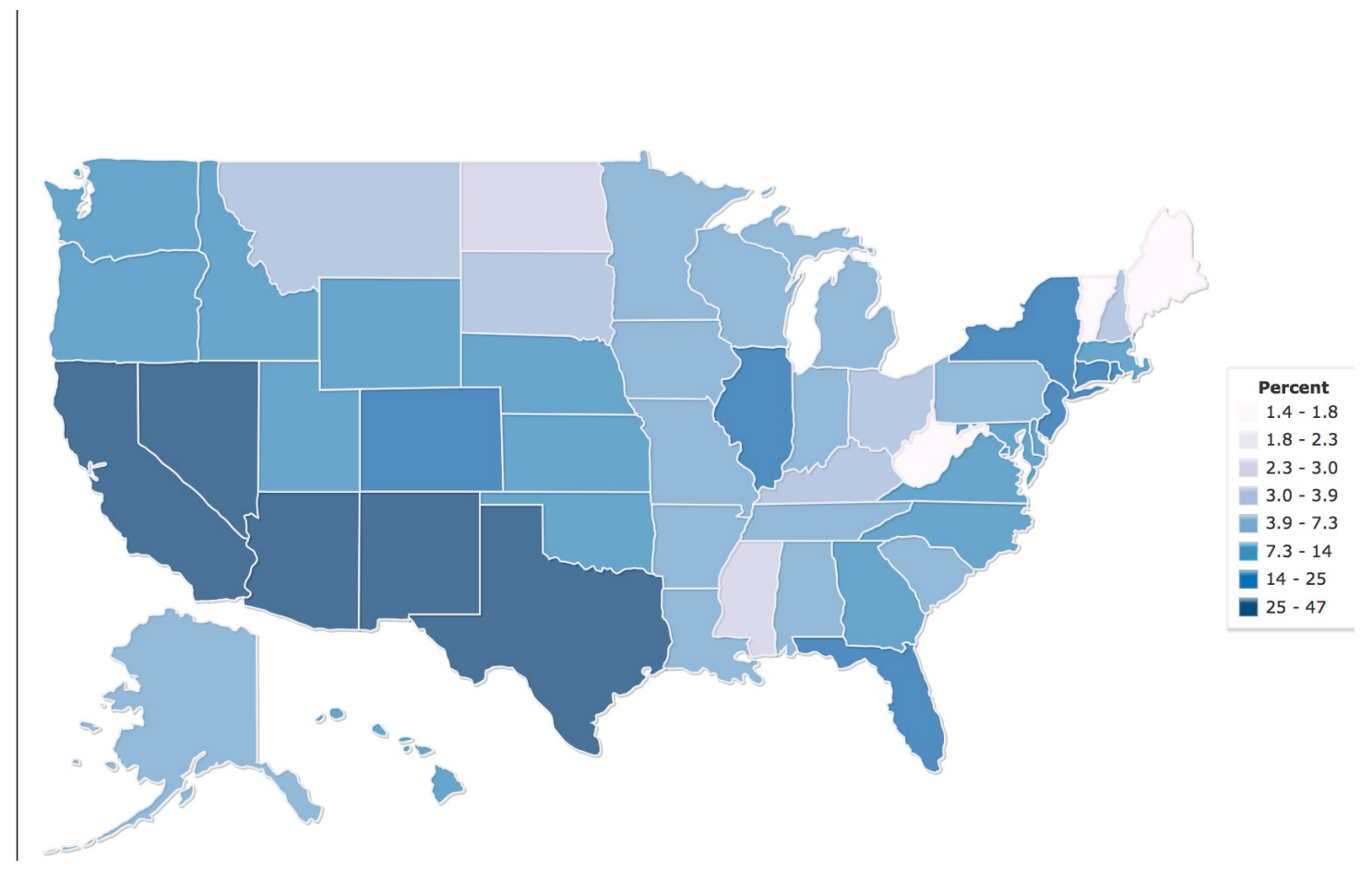

Courtesy of IndexMundi. 


\section{$\underline{\text { Swing States: The Growing Hispanic Population }}$}

An analysis of individual U.S. states allows one to break down the Latino vote into smaller, more understandable pieces, offering a snapshot of Latino political leanings, but also of demographic growth and transformation. As of 2014, "eight states had Latino populations of at least 1 million: California, Texas, Florida, New York, Illinois, Arizona, New Jersey and Colorado" (Stepler and Lopez 2016). These eight states represent a demographic trend at work, an increase in Hispanic residents in the U.S., many of whom will participate in American democracy. Figure 2 demonstrates the degree of concentration of the U.S. Hispanic population in specific states. Texas, Florida, Colorado and Arizona are four battleground states with demographic landscapes that have changed dramatically in recent decades and provide insight into future national and state electoral contests. These four states have a substantial concentration of Hispanic residents and voters that is poised to grow exponentially in the next decade. Arizona and Texas are entering a new political era as swing states, where Democrats can realistically compete at the state level and eventually in their quest to add both states to their Electoral College gains. Florida is a swing state that could slowly become a Democratic stronghold due to its large and growing Latino population. Colorado presents the political reality of a state that has already undergone significant changes due to a significant Hispanic population and electorate. All four states will prove instrumental over the next decade in any Electoral College win and could likely swing Democratic due to potentially decisive Latino electorates. 
Texas: "Nearly one-in-five Hispanics nationwide (19\%) reside in Texas, where the Hispanic population reached 10.4 million in 2014" (ibid). Turnout in Texas increased demonstrably in every heavily Latino county during the 2016 presidential election. For example, "in the strongly 90 percent Latino counties in the Rio Grande Valley, turnout increased 4 to 10 percent over 2012" (Sanchez and Barreto 2016). Turnout in these largely Latino precincts portends an increasingly impactful Hispanic voting bloc in Texas that could potentially affect the states overall electoral outcome.

Texas exit polls report that 61 percent of Hispanics voted for Clinton in the 2016 presidential election, but a detailed analysis of precinct results within the state points to different numbers (Pedraza and Wilcox-Archuleta 2016). According to data from 4,372 precincts across Texas, "Clinton won 560,000 more votes in Texas than Obama did in 2012" (ibid). Additionally, voter turnout across the state was two points higher in 2016 than in 2012, with Hispanics representing "the fastest-growing segment of the Texas electorate" (ibid). Clinton's victory among Texas Hispanics is further evident in the fact that Clinton won more votes in almost all precincts than Obama did in 2012, and especially in those that are largely Hispanic (ibid). These gains across Texas for the Democratic candidate, could have been slightly offset by the white backlash that was spurred by Trump's candidacy and rhetorical fervor. However, due to Texas' growing Hispanic demographic the next decade will see a dramatic shift in the conventional wisdom of the Electoral College, if Latinos is Texas remain strident supporters of Democratic presidential candidates. 
Within the 864 Texas precincts in which three quarters or more of the voters are Hispanic, Clinton captured more votes than Obama did in 2012 in 723 of them (Pedraza and Wilcox-Archuleta 2016). In rural Texas counties, "Clinton won an estimated 77 percent of the Latino vote against 19 percent for Trump," while in medium-sized Texas counties "Clinton won an estimated 73 percent of the Latino vote—-still 12 points higher than the exit poll estimate of 61 percent" (ibid). The exit poll results seem especially inaccurate when one considers Clinton garnered 80 percent of the Latino vote in large Texas cities, while Trump amassed a mere 14 percent (ibid). Overall, the precinct data leads to an estimation of 77 percent of Hispanics for Clinton in Texas, a closer approximation to the Latino Decisions Election Eve Poll results than exit polling done throughout the state (ibid). Precinct data ideally captures a more accurate sampling of voters than exit polls, whose proponents even recognize the inherent faults. On the other hand, turnout among Hispanics is relatively dismal and must be included in any estimation or prediction of the effect the Latino voting bloc has on a particular election or the popularity of a particular candidate.

Latino turnout in Texas has lagged in recent presidential elections, even compared with national Latino turnout. Only 39 percent of eligible Latinos voted in Texas in 2012, while 48 percent turned out nationwide (Ratcliffe 2016). Trump's candidacy in the 2016 election may have provided a unique playing field for Democrats, as his remarks regarding immigrants and Mexicans throughout the campaign alienated many Hispanic voters. In future elections, Texas Republican candidates may court the Latino vote as many succeeded in doing in past elections. Apart from George W. Bush's historic precedent, Re- 
publican U.S. Senator John Cornyn of Texas captured 48 percent of the Latino vote in 2014 and Texas Governor Greg Abbott received 44 percent of the Latino vote in his victory over Democrat Wendy Davis (ibid). The Latino population in Texas clearly differs from many solidly Republican states, and even some swing states, because of the sheer concentration of Latinos and Texans' embrace of Latino culture in many aspects of everyday life (i.e., Tex-Mex cuisine, quinceañeras). Due to the indelible link between Hispanic immigrants, Hispanic Americans and non-Hispanic white Americans in Texas, Republicans and Democrats in this border state will continue to both vie for a majority of voters through positive rhetoric and policies towards Hispanics.

Some experts argue that an eventual Democratic trajectory in Texas politics in indisputable. While Trump clearly won Texas in the 2016 election, he only carried it by 9 points (Suro 2016). Clinton outperformed Obama in Texas by 600,000 votes, compared with his 2012 results, and Trump only received "112,000 more votes than Romney" (Cohen 2016). Cohen (2016) asserts: "Texas may still be a cycle or two away from being competitive, but Democrats have some reason to believe they can challenge Republicans there." Obama lost Texas to Romney in 2012 by nearly 16 points and by almost 12 points in his 2008 contest against McCain (Suro 2016). An influx of Americans relocating to Texas from other states and Latinos from abroad and within the U.S. is beginning to transform the state and will likely eventually transform its political structure, as it did in Colorado and Nevada, two swing states that faced similar demographic changes within the last decade (ibid). The Secretary of State's office in Texas recorded 15 million registered voters in 2016, an increase of 1.7 million from 2012 and "Hispanic surname voters 
account for 30 percent of that increase" (ibid). Turnout among Hispanics and possible Republican support from this voting bloc may diminish a Democratic surge in future elections, but the demographic shift underway is indisputable and will prove consequential. This formula of demographic diversification will likely affect other states as well. Arizona: In Arizona, Latinos represent 22 percent of eligible voters, making it the state with the fourth largest Latino eligible voter population (America's Voice). A decisive 87.7 percent of Arizona's Latino population is of Mexican descent, a figure that certainly impacted Trump's lack of support among Hispanics within the state (ibid). Trump's disparaging comments about Mexicans, specifically, likely galvanized support for his Democratic opponent and weakened his position within the state. Latinos comprised 18 percent of voters in Arizona in 2012, but 22 percent in 2014 (ibid). In an August 2016 Latino Decisions poll, 79 percent of likely Latino voters in Arizona said they held an unfavorable view of Trump, with 71 percent "of total respondents classifying their opinion as very unfavorable" (ibid). The Republican Party's reputation as a whole also suffers among Latinos in Arizona. Latino Decisions found that 31 percent of "Arizona likely Latino voters view the Republican Party as sometimes hostile to Latinos, and 45 percent think the party doesn't care too much about Latinos" (ibid). As nearly one-third of Arizona's population (31 percent) as of 2014, Latinos in this traditionally Republican stronghold stand to alter the electoral status quo in the years to come (Stepler and Lopez 2016). Arizona can now be considered a battleground state, in which Democrats and Republicans will equally vie for its voters' support in every election, which includes a growing Latino demographic. 
In a nod to the Latino Decisions Election Eve Poll results, two political scientists analyzed precinct-level voting results across Arizona to determine the validity of exit polls (Nuño and Wilcox-Archuleta 2016). The "ecological fallacy" could explain why county-level data in exit polls are inadequate and unreliable (ibid). Stephen Nuño and Bryan Wilcox-Archuleta (2016) gathered data for 1,288 of the nearly 1,500 precincts in Arizona and found that it was statistically unlikely that exit polls were correct about Clinton's Latino support, and found "strong evidence that over 80 percent of Latinos in Arizona voted for Clinton, a number much closer to the Latino Decisions estimate" (ibid). Their use of an ecological inference technique in their precinct analysis led them to estimate that a record 550,000 Latino voters supported Clinton; the Democratic candidate only lost the state by a 4-point margin, narrowing Obama's 2012 loss to Romney by 5points (ibid). Nuño and Wilcox-Archuleta (2016) argue that exit polls often overrepresent the "views of Latino voters with higher income and education levels than most of the Latino voting community and have failed to include enough Spanish-speaking Latino voters" to ensure accuracy (ibid). In their comparative analysis of other states' precinct data, compared to Texas', Pedraza and Wilcox-Archuleta (2016) "estimate that Clinton won more than 80 percent of the Latino vote" in Arizona. Their estimation, based on smaller sectors of the state call exit poll results into question, even more than is typical, and aligned more directly with the Latino Decisions results.

Arizona is quickly entering the swing state category in nearly all Electoral College matchups due to its growing Hispanic population that is poised to become a majority in the state by 2030 (Santos 2016). Backlash is evident in Arizona's 2010 passage of 
Senate Bill 1070 and in Arizona's infamous Sheriff Joe Arpaio's incendiary rhetoric and anti-immigrant actions. Arpaio served six terms before losing his bid for a seventh term during the 2016 election (ibid). The former sheriff enjoyed support from older white and conservative voters who "propelled him to victory every four years for six elections, pumping millions of dollars into his campaign" (ibid). Legal challenges to his unforgiving and illegal anti-immigrant and blatantly anti-Latino policies, as well as a growing Hispanic population in Arizona, ensured his ultimate defeat (ibid). Arpaio's defeat, along with Clinton's narrow loss of the state, portend a Democratization of Arizona.

Colorado: Colorado offers a window into the possible future of Arizona and Texas, states with growing Latino populations, a fact that contributed greatly to Colorado's status as a swing state and the hotly contested election cycle fights by both Democrats and Republicans. Interestingly, "Latino support for the Republican Party in national elections in Colorado grew significantly between 1996 and 2008," peaking at 38 percent and in 2012, only 23 percent of Latinos supported the Republican candidate in the voting booth (America's Voice). A Latino Decisions poll conducted in 2014 found that 42 percent of Latinos in Colorado "said that Republicans 'don't care too much' about the Latino Community" (ibid). They further found that 45 percent of Colorado Latinos have all but written off the Republican Party, "saying that the party 'has now become so anti-immigrant, and antiLatino that it would be hard for me to consider supporting them"' (ibid). Nearly 46 percent of Colorado's immigrants are Mexican and a 2016 Latino Decisions poll found that 59 percent "of Colorado's Latinos say they personally know an undocumented immigrant" (ibid). Trump's disparaging comments regarding Mexicans and undocumented 
immigrants surely alienated many of these Colorado voters who personally recognize the struggles many undocumented individuals face in their state and in the U.S.

Trump's rhetoric clearly affected his favorability among Latinos in Colorado, 81 percent of whom have an unfavorable view of Trump, and 74 percent of whom view him “very unfavorably" (America's Voice). This unfavorable view extends, for Latinos, from Trump to the entire Republican Party as a whole. In the 2016 Latino Decisions poll, 76 percent of respondents "said that Donald Trump has made the Republican party more hostile to Latinos" (ibid). This figure may dissipate if future presidential candidates attempt to court Latinos in a more effective manner than Trump, but if it persists among Latinos in Colorado, the Republican Party will have difficulty solidifying a strong enough base of support to compete statewide. The relentless pace of demographic diversification within Colorado is evident, as "11,000 Latino immigrants are estimated to have become citizens and an estimated 67,000 young Latino citizens have turned 18 " in Colorado since 2012 (ibid). While not all of these potential voters will turn out on Election Day, between 2012 and 2020, "there will be an estimated 168,606 additional eligible Latino voters" in Colorado who will warrant attention from any serious political contender (ibid). With the potential to register even more Latino voters in Colorado, this demographic is poised to change not only the demographic make-up but political trajectory of the state. In 2012, the "number of Latino eligible voters who are not yet registered" was 213,000, "a number larger than the population of all but three of Colorado's cities" (ibid). Florida: Florida appears poised to follow Colorado's lead in turning Democratic in future elections as Trump's razor-thin win in the Sunshine State elucidated. The swing state has 
4.8 million Hispanics, accounting for 24 percent of Florida's population (Stepler and Lopez 2016). Latinos have an irrefutable affect on statewide and local political elections. In any discussion of Florida voting patterns, the Hispanic voting bloc and its many permutations, must be included in the political calculus. In the 2016 election, Sanchez and Barreto (2016) found that the oft-discussed, traditionally conservative, Cuban vote in Florida won Clinton 67 percent of the Latino vote in Florida, while she accrued 88 percent in New York and above 80 percent in many states. Even though she garnered less support among Latinos than in other states, Clinton gained more support than Obama, who received only 58 percent of the Florida Latino vote in 2012 (Sanchez and Barreto 2016). Additionally, in “heavily Latino precincts across Florida's Miami and Osceola counties, voter participation increased from 6 to 16 points" (ibid). Clinton successfully won more net votes than Obama in 88 percent of Floridian precincts that are 75 percent or more Latino in the 2016 election (Valenzuela and Reny 2016). Clinton's campaign clearly mobilized support among Latinos in Florida and used Trump's alienating comments regarding Mexicans and immigrants to draw support to the Democratic ticket. Trump's comments most likely encouraged Latino support for Clinton, but other factors, including Obama's policy change on Cuba likely negatively affected her candidacy in Florida.

While Clinton outperformed Obama and Trump underperformed Romney in nearly every Florida precinct with a Latino population above 40 percent, "Trump (and Romney) beat Clinton (and Obama) in the most heavily Latino precincts in Miami-Dade" (Valenzuela and Reny 2016). The high concentration of Cubans in Miami-Dade County, 
many of whom voted for Trump in the 2016 presidential election, explains this seemingly paradoxical phenomenon (ibid). However, even in every Miami-Dade precinct with a concentration of Hispanics above 40 percent, Clinton captured more of the vote than Obama did four years earlier; clearly Trump "still won a reasonable number of votes in Cuban-American enclaves in Miami, there is no question that he won far less than Romney from Latinos in Miami” (ibid). Representing 29 percent of the Hispanic population in Florida, the Cuban vote is often decisive in, or at the very least, important to presidential elections (ibid).

Cubans, though, have become more diverse; in 2014, 44 percent of "Cubans in the U.S. were native-born," and those born in the U.S. are often not as focused on the ColdWar politics that plagued their family's homeland (America's Voice). Unlike their Republican elders who often reacted politically against the difficulties of the socialist regime in Cuba, younger Cubans (between 18 and 49) "now identify or lean to the Democratic Party by $56 \%$ compared to $23 \%$ who identify with or lean to the Republican $[P]$ arty" (ibid). This shift in party affiliation among younger Cuban-Americans demonstrates a change in Florida politics and a potentially pivotal national political evolution. "In 2000, George W. Bush won 81\% of the Cuban vote in Florida" and in 2012 "President Obama picked up $49 \%$ of the Cuban vote compared to the $47 \%$ who went for Romney" (ibid). Importantly, Cubans are no longer nearly synonymous with Florida Hispanics. In 2014, "Cubans comprised less than a third-29.5\%—of the Latino population in Florida," with the next three largest groups comprising 42 percent (Puerto Ricans, Mexi- 
cans, and Colombians) (ibid). Hispanics are not a monolithic group, but Florida's Cuban population has long captured the interest of social scientists and political analysts.

In a consistent move away from the conservative Republican fold in Florida politics, Cubans represent a possible foothold for Democrats in future elections. Clinton only lost the state of Florida to Trump by a little over 100,000 votes, with 47.4 percent to Trump's 48.6 percent (“Presidential Election Results: Donald J. Trump Wins” 2016). Clinton's narrow loss signifies an important opportunity for Democrats and a dramatic shift in the Electoral College calculus. Latinos "accounted for $88 \%$ of the growth in the number of registered Democrats in Florida" in the decade between 2006 and 2016, and now "registered Democrats outnumber registered Republicans in the state among Latino voters" (America's Voice). As noted previously, Hispanic growth in the Southern and Western U.S. could alter the traditional Electoral College map. As the 2016 presidential election demonstrated, the Midwest and Rust Belt are no longer Democratic strongholds and illuminate a move of older, white, working-class voters to the Republican Party. These seismic political shifts reveal a new normal in presidential politics. Trump was a unique candidate who unusually alienated Latinos across the country. While Romney secured 39 percent of the Latino vote in Florida in 2012, Trump only received 35 percent (Krogstad and Flores 2016). A one-point margin of victory in Florida may not represent the new status quo in U.S. presidential elections. Trump's unique candidacy and his galvanization of the white vote, especially in Florida, and alienation of Hispanics are likely anomalies in modern presidential politics that will rarely, if ever, be replicated. 
Clinton's narrow loss in Florida and Arizona portends a change in these states' demographic make-up and electoral leanings. Trump's unusually alienating rhetoric may have provided a unique opportunity to view electoral shifts in the coming decades, as he likely received less of the Hispanic vote than a future Republican candidate who would actively court the Latino voting bloc. On the other hand, whether exit polls or the county and precinct analysis done by Latino Decisions and others, are correct, Trump indisputably garnered Hispanic support among religious, socially conservative and rural Hispanics.

These four swing states, Texas, Arizona, Colorado, and Florida, provide a window into the 2016 presidential election and present context for changes in future demographic shifts that will indubitably affect electoral contests for years to come. The Hispanic voting bloc in each of these critical states will not only continue to grow, but will become more influential as Hispanic voters acquire more resources and develop political networks in their communities. It will be impossible for political candidates to ignore the potentially decisive power of Latino voters, especially in these four states, as Hispanics continue to immigrate, gain citizenship and age into voting. The next decade will see a shift of these four swing states (and others) to the "lean Democratic" column in the transitioning Electoral College calculus. White, economic, transactional voters in the Midwest and Rustbelt will turn those states Republican, as many did for Trump in the 2016 presidential election (e.g. Wisconsin, Pennsylvania, Ohio, Michigan). The Hispanic electorate, though, is clearly growing exponentially and votes overwhelmingly Democratic. As Hispanic populations grow outside of California and New York (two Democratic 
strongholds), the Hispanic electorate will determine Electoral College contests in key states.

\section{Conclusions}

Given the idiosyncratic nature of the 2016 presidential contest, it is unlikely that any future Republican candidate will be able to recreate the same confluence of factors that Trump was able to secure in order to propel himself to the White House. Demographics are also steadily diversifying, ensuring that any strategy based almost entirely on white voter mobilization will be self-destructive. Republican presidential candidates in the future will be forced to contend with the unavoidable reality of an increasingly racially diverse electorate and a shrinking base of white voters. A diverse demography will eventually increase the diversity within the electorate, diminishing the ability of any candidate to run a national campaign based on anemic minority support. Growth of the Hispanic population and electorate in critical swing states (i.e., in Florida, Colorado, Arizona and Texas) will inevitably alter the political calculus and strategy of any future national campaign. This shift is already evident in the popular vote and in certain Democratic strongholds (e.g. California). Hispanic voters are far from monolithic, but they do tend to support Democrats. The 2016 popular vote, which Clinton won by nearly three million votes, demonstrates the sizable Democratic advantage nation-wide ("Presidential Election Results: Donald J. Trump Wins" 2016). New York and California further illustrate the sheer growth of Hispanics in the U.S. population and the electorate.

Texas and Arizona, especially, represent traditional Republican strongholds that are moving not only into the swing state category, but are on a Democratic trajectory due 
to their dramatic demographic shifts. Latino populations within these states are clearly growing exponentially. Electoral turnout will subsequently increase as immigrants and the young Latino population gain the opportunity to vote and are more comfortable in the voting booth. Civic education among the Latino population will be crucial for the Democratic Party in the coming decades. The immigrant threat narrative espoused by Republicans and perpetuated by the media will continue to feed fears among a mostly rural, white, working-class population who resent the demographic change occurring throughout the U.S. and seek a scapegoat. However, as Hispanics continue to grow as a constituency, and engage in communities across the U.S., the shrinking white electorate will undoubtably grow less consequential in national and state elections.

The 2016 presidential election was remarkable in its unusual and historic nature. Both candidates were unique and divided the country in unprecedented ways. In a more traditional breakdown, minorities and city dwellers largely flocked to Clinton, while white and rural voters supported Trump. White women, though, supported Trump over Clinton, giving Trump a sizable advantage of suburban female voters in crucial Midwest and Rust Belt states. Third party candidates also likely siphoned support from Clinton, especially in the Midwest and among Millennials. As opposed to the overzealous commentary among pundits leading up to the election, the Hispanic vote did not prove decisive enough to hand Clinton the presidency. The 2016 presidential election does illuminate the future Electoral College trajectory of many swing states that will likely shift from Republican to Democratic strongholds as the Hispanic electorate continues to grow. However, the emerging Democratic majority has been emerging for decades and Trump 
was still able to secure victory in 2016 . While the eventual trajectory of many states and the nation points to a Democratic majority (if all other conditions remained the same), the 2020 presidential election is unlikely to demonstrate this demographic change.

Hispanics continue to largely orient themselves in Democratic strongholds (e.g., California and New York). Slowly, Hispanic Americans will move throughout the U.S., as is already occurring, and eventually will affect politics in newly-minted swing states. The 2020 and 2024 presidential elections will undoubtedly show signs of this transition in Florida, Arizona, and even Texas (among others). Depending upon white backlash, the immigration rate and district-wide politics (e.g., voter identification laws, gerrymandering), the Hispanic electorate could emerge as early as 2020 as a major factor in national elections. Latinos will likely not prove decisive for several more election cycles, though, due to the impediments discussed herein. If current conditions remain constant, the growing Hispanic population will translate eventually into a competitive Hispanic electorate that, along with other minority electorates, will eventually eclipse white voters in U.S. elections.

In the decades to come, growth of minority electorates will alter the Electoral College calculus and change the traditional map of party affiliation. Geography, not demography ruled the 2016 election (in terms of race and ethnicity, not necessarily gender), but it required unprecedented and unsustainable turnout from the white electorate in specific swing states. Demographic change will soon overwhelm whatever geographic breakdown favored Trump in 2016 and any future Republican presidential candidate, if the Party maintains its policy positions. Hispanic voter turnout may be low, but precinct analysis 
within certain swing states elucidates the electorate's trajectory. The growing Hispanic population, and subsequently the Hispanic electorate, will prove critical in future presidential elections, especially as they reach a threshold that may temper some unease and backlash from white voters. Precinct breakdowns in Texas and Arizona, especially, demonstrate that a significant and growing Hispanic population and electorate will soon prove decisive in national and state elections.

The Republican Party does have an opportunity to court Hispanics, especially if they moderate their immigration policy. Hispanic and white rural voters supported Trump based on policy prescriptions and promises made to improve their economic situations. Some of these transactional voters supported Trump based on religious and social issues (e.g., abortion, gay marriage). Exit polling clearly failed to represent certain aspects of the Hispanic vote due to an over reliance on English speaking, richer and better educated Hispanic voters. On the other hand, Latino Decisions' precinct analysis may not have included enough rural Hispanics who supported Trump for economic or social reasons and only surveyed likely voters before the 2016 presidential election. Both polling methods are flawed in different ways, but do present important information regarding Trump's narrow Electoral College victory and popular vote loss. An obvious reason for Trump's win is his galvanization and mobilization of white voters, especially in crucial swing states, while still managing to win traditionally Republican, southern states. While he lost ground in Texas and Arizona, he was able to add both to his Electoral College vote total, ensuring victory when coupled with his slight wins in Pennsylvania, Wisconsin and Michigan. 
Clinton outperformed Obama's 2012 vote totals in precincts across Florida, Arizona, and Texas, but Trump's support from white voters, and some Hispanic voters, assured his Electoral College win. Backlash among white voters against rapid social and demographic change clearly lent Trump a vital edge in his bid for the presidency. The immigrant threat narrative stoked fears among white voters, many of whom turned out for the first time in years in order to support Trump. A growing Hispanic population across the U.S. galvanized Trump supporters who are alarmed by their changing communities and country. Turnout among white voters was unprecedentedly high, while Millennials, Hispanics and Asians all had relatively low turnout by comparison. As those turnout numbers begin to grow among minorities and younger Americans, and as white voters continue to diminish as an electorate, the Electoral College will skew Democratic in southern swing states (e.g., Texas, Florida, Arizona). The Midwest and the Rustbelt may have leaned Republican in the 2016 election, but only by a narrow margin. Trump's victory does not portend future Republican wins in those regions, as it is unlikely that white voters will turn out in droves, while Millennial and minority voters fail to reach parity in terms of turnout. Demographic changes in the U.S. are apparent and unstoppable. A diversifying electorate will alter the political calculus for the foreseeable future and make Trump's win one last hurrah for the Republican Party (if the Party fails to change with the electorate).

Trump's transactional voters also pose a problem for his reelection prospects or future Republican presidential bids. If Trump fails to deliver on his promises to improve the economic well-being of these mostly rural and suburban workers, he stands to face 
severe repercussions in his support among Americans. His promises to bring back coal and manufacturing jobs clinched his narrow win in states like Michigan, Pennsylvania and Wisconsin. His Electoral College victory was entirely dependent upon these voters' support. Even a contingent of Hispanic voters chose to overlook his alienating rhetoric in favor of his promises to ensure economic prosperity for them and their communities. These voters may simply fail to turnout and vote in 2020 if Trump cannot deliver on promises that most experts deem implausible due to our globalized economy and technological advances in labor-production techniques.

Demography continues to favor the Democrats. As turnout among diverse groups of Americans increases, and the white population decreases, the electoral calculus will favor the Party that embraces diversity and is championed by the young. If the Republican Party fails to adapt to this inevitable change, no amount of gerrymandering or galvanization of white voters will be able to defeat an inclusive Democratic Party. Turnout efforts will continue to determine the outcome of presidential elections, especially in the near future, but demographic diversification is undeniable in critical swing states and across the U.S. Clearly, pundits and social scientists misjudged the decisive nature of the Hispanic vote in their rush to claim that the "sleeping giant" would elect Clinton in 2016. Demographics, especially a growing Hispanic electorate, will eventually alter the Electoral College landscape and flip likely Republican swing states to likely Democratic swing states, but such change may not be fully realized in 2020, or even 2024. The 2016 presidential election demonstrated that white backlash against diversification and in response to an immigrant threat narrative perpetuated by the Republican Party can ensure a 
narrow victory, at least in an election between major party candidates Clinton and Trump. Turnout among minority voters and young Americans continues to lag behind that of white voters, a fact that was particularly apparent in this election.

White, rural, and Hispanic Trump voters (as well as various factors surrounding Clinton's candidacy) coalesced to yield Trump a narrow Electoral College victory, despite his overwhelming loss to Clinton in the popular vote. Geography, as opposed to demography, determined the 2016 presidential election. Importantly, though, demographic change was evident in key swing states, elucidating a change that will eventually significantly affect the U.S. electorate. White voters, along with some minority voters from rural areas, handed Trump the presidency in their unprecedented turnout around the country but especially in Pennsylvania, Wisconsin and Michigan. Despite losing ground, compared to Romney's 2012 results, in southern and southwestern states, Trump managed to secure Electoral College votes from Arizona, Florida, and Texas. All three states, though, appear poised to swing Democratic in future elections as their Hispanic populations balloon, nudging the states' electorates in a different direction.

While polling before and after the 2016 presidential election is inconsistent, it is obvious that the Hispanic electorate is not a monolithic group and in some ways may naturally favor the Republican Party. Historically, though, Hispanics lean Democratic ensuring Democratic wins due to demographic gains as Hispanics continue to rapidly grow as a population and an electorate in the U.S. Republicans could learn from Hispanics' reactions to alienating rhetoric and fear mongering and alter their Party's platform to remain competitive in future national and state elections. The 2016 presidential election illumi- 
nates clear divisions within the U.S. and the largely unexpected voting power of the diminishing white electorate. Trump's unique coalition demonstrated urban/rural as well as racial divides that will undoubtedly haunt future presidential elections. The 2016 presidential election demonstrates an aberrant confluence of factors that ensured an Electoral College victory based on white voter mobilization, transactional voter support, and structural and individual impediments to Latino turnout despite America's demographic future in which the Hispanic electorate will have a decisive role in national and local elections. The Hispanic electorate may not determine the 2020 presidential election, but it will prove decisive in national elections within the decade due to its exponential growth that will nullify the effect of some structural and individual impediments to voting. 


\section{Work Cited}

Abrajano, Marisa A., et al. 2008. "The Hispanic Vote in the 2004 Presidential Election: Insecurity and Moral Concerns”. The Journal of Politics. 70:368-382.

Abrajano, Marisa, and Zoltan L. Hajnal. 2015. White Backlash: Immigration, Race and American Politics. New Jersey: Princeton University Press.

Affigne, Tony. 2000. "Latino Politics in the United States: An Introduction". PS: Politi cal Science \& Politics. 33:523-525.

America's Voice. "Latino and Immigrant Voters in the 2016 Election". http://americasvoice.org/latino-immigrant-voters-2016-election/

Barabak, Mark. 2017. "Pete Wilson looks back on Proposition 187 and says, heck yeah, he'd support it all over again". The Los Angeles Times.

Barreto, Matt A., et al. 2008. “'Should They Dance with the One Who Brung 'em?' Lati nos and the 2008 Presidential Election". PS: Political Science and Politics. 41:753-760.

Borjas, George. 2016. "Yes, Immigration Hurts American Workers". Politico Magazine. September/October.

Cadava, Geraldo L. 2016. "Rural Hispanic voters — like white rural voters — shifted toward Trump. Here's why." The Washington Post.

Cecil, Guy. 2017. "New research for Priorities USA shows opportunity for Democrats among those voters who were decisive in the 2016 election". Priorities USA and Garin Hart Yang and Global Strategy Group.

Cohen, Michael A. 2016. "By the numbers: How Donald Trump won”. The Boston 
Globe.

Collingwood, Loren, et al. 2014. "Revisiting Latino Voting: Cross-Racial Mobilization in the 2012 Election”. Political Research Quarterly. 67:632-645.

“County Economies”. 2016. National Association of Counties. NACo Futures Lab.

Crotty, William J. 1991. Political Participation and American Democracy. Greenwood Press.

Dinan, Stephen. 2016. “Donald Trump’s win leaves Hispanics wondering if their influ ence has waned on issues". The Washington Times.

Enten, Harry. 2016. “Trump Probably Did Better With Latino Voters Than Romney Did". FiveThirtyEight.

Frey, William. 2014. Diversity Explosion: How New Racial Demographics are Remaking America. Washington D.C.: Brookings Institution Press.

Gamboa, Suzanne. 2016. "What Machismo? Latino Men Overwhelmingly Voted for Clinton". NBC News.

Gomez, Alan. 2016. "Another election surprise: Many Hispanics backed Trump”. US Today.

Herrnson, Paul S., et al. 2013. "Exceeding Expectations? Determinants of Satisfaction with the Voting Process in the 2008 U.S. Presidential Election”. The Journal of Politics. 75:451-463.

Hopkins, Daniel. 2010. "Politicized Places: Explaining Where and When Immigrants Provoke Local Opposition”. The American Political Science Review. 104: 40-60. Jackson, Melinda. 2011. "Priming the Sleeping Giant: The Dynamics of Latino Political 
Identity and Vote Choice”. Political Psychology. 32:691-716.

Judis, John B., and Ruy Teixeira. 2002. The Emerging Democratic Majority. New York: Lisa Drew/Scribner.

Khalid, Asma. 2016. “Latinos Will Never Vote For A Republican, And Other Myths About Hispanics From 2016”. National Public Radio.

Kilgore, Ed. 2016. “Why Latino Voters Didn’t Bury Trump”. New York Magazine.

Krogstad, Jens Manuel, and Antonio Flores. 2016. "Unlike other Latinos, about half of Cuban voters in Florida backed Trump". Pew Research Center.

MacGillis, Alec. 2016. “The Gang that Failed”. The New York Times. September 18. Náñez, Dianna M. 2016. "Why these African-Americans and Latinos are voting for Trump". azcentral: The Arizona Republic.

Nicholson, Stephen P., et al. 2006. "Political Knowledge and Issue Voting among the Latino Electorate". Political Research Quarterly. 59:259-269.

Noel, Andrea. 2016. "Mexican-American Trump Voters: Pulling Up the Ladder". The Daily Beast.

Nuño, Stephen A., and Bryan Wilcox-Archuleta. 2016. "Viewpoints: Why exit polls are wrong about Latino voters in Arizona". azcentral: The Arizona Republic.

Pedraza, Francisco, and Bryan Wilcox-Archuleta. 2016. "Donald Trump did not win 34\% of Latino vote in Texas. He won much less." The Washington Post.

Petersen, Anne Helen. 2016. "Meet The Ivanka Voter”. Buzzfeed News.

Portes, Alejandro and Rubén G. Rumbaut. 2001. Legacies: The Story of the Immigrant Second Generation. University of California Press. 
“Presidential Election Results: Donald J. Trump Wins". 2016. The New York Times. https://www.nytimes.com/elections/results/president

Ramakrishnan, Karthick. 2016. "Trump got more votes from people of color than Rom ney did. Here's the data." The Washington Post.

Ratcliffe, R.G. 2016. “Texas Sees a Surge in Latino Voters”. Texas Monthly.

Rogers, Katie. 2016. "White Women Helped Elect Donald Trump”. The New York Times.

Salvanto, Anthony, et. al. 2017. “Poll: Does Trump's support have a ceiling — or a floor?" CBS News.

Sanchez, Gabriel and Matt A. Barreto. 2016. "In record numbers, Latinos voted over whelmingly against Trump. We did the research." The Washington Post.

Santos, Fernanda. 2016. "Sheriff Joe Arpaio Loses Bid for 7th Term in Arizona". The New York Times.

Stepler, Renee, and Mark Hugo Lopez. 2016. "Ranking the Latino population in the states". Pew Research Center.

Suro, Roberto. 2016. "Here's What Happened with the Latino Vote". The New York Times.

Taylor, Paul. 2014. The Next America: Boomers, Millennials, and the Looming Genera tional Showdown. New York: PublicAffairs.

Valdes, Marcela. 2016. "Dream in Blue”. New York Times Magazine.

Valdes, Marcela. 2016. "'We're Looking at a New Divide Within the Hispanic Commu nity". The New York Times Magazine. 
Valenzuela, Ali, and Tyler Reny. 2016. "Study: Trump fared worse than Romney in Flor ida Hispanic vote". The Hill.

Walter, Amy. 2017. “Trump's Transactional Voters”. The Cook Political Report. 